\title{
Homo-Tris-Nitrones Derived from $\alpha$-Phenyl-N-tert- butylnitrone: Synthesis, Neuroprotection and Antioxidant Properties
}

\author{
Daniel Diez-Iriepa ${ }^{1,2,+}$, Beatriz Chamorro ${ }^{3,4, \dagger}$, Marta Talaván ${ }^{3}$, Mourad Chioua ${ }^{1}$, \\ Isabel Iriepa ${ }^{2,5}{ }^{(\mathbb{D}}$, Dimitra Hadjipavlou-Litina ${ }^{6}{ }^{(}$, Francisco López-Muñoz ${ }^{4,7}$, \\ José Marco-Contelles $^{1, *}$ and María Jesús Oset-Gasque ${ }^{3,8, *(\mathbb{D})}$ \\ 1 Laboratory of Medicinal Chemistry, Institute of Organic Chemistry (CSIC), Juan de la Cierva 3, \\ 28006 Madrid, Spain; daniel.diezi@uah.es (D.D.-I.); mchioua@gmail.com (M.C.) \\ 2 Department of Organic Chemistry and Inorganic Chemistry, Alcalá University, Alcalá de Henares, \\ 28805 Madrid, Spain; isabel.iriepa@uah.es \\ 3 Department of Biochemistry and Molecular Biology, Faculty of Pharmacy, Complutense University of \\ Madrid, Plaza Ramón y Cajal s/n, Ciudad Universitaria, 28040 Madrid, Spain; beatrcha@ucm.es (B.C.); \\ martalav@ucm.es (M.T.) \\ 4 Faculty of Health, Camilo José Cela University of Madrid (UCJC), 28692 Villafranca del Castillo, Spain; \\ flopez@ucjc.edu \\ 5 Institute of Chemical Research Andrés M. del Río, Alcalá University, Alcalá de Henares, 28805 Madrid, Spain \\ 6 Department of Pharmaceutical Chemistry, School of Pharmacy, Faculty of Health Sciences, \\ Aristotle University of Thessaloniki, 54124 Thessaloniki, Greece; hadjipav@pharm.auth.gr \\ 7 Neuropsychopharmacology Unit, "Hospital 12 de Octubre" Research Institute, 28041 Madrid, Spain \\ 8 Instituto Universitario de Investigación en Neuroquímica, Universidad Complutense de Madrid, \\ 28040 Madrid, Spain \\ * Correspondence: iqoc21@iqog.csic.es (J.M.-C.); mjoset@ucm.es (M.J.O.-G.) \\ $\dagger$ These authors have equally contributed to this work.
}

Received: 5 October 2020; Accepted: 21 October 2020; Published: 26 October 2020

\begin{abstract}
Herein we report the synthesis, antioxidant and neuroprotective power of homo-tris-nitrones (HTN) 1-3, designed on the hypothesis that the incorporation of a third nitrone motif into our previously identified homo-bis-nitrone 6 (HBN6) would result in an improved and stronger neuroprotection. The neuroprotection of HTNs 1-3, measured against oligomycin A/rotenone, showed that HTN2 was the best neuroprotective agent at a lower dose $\left(\mathrm{EC}_{50}=51.63 \pm 4.32 \mu \mathrm{M}\right)$, being similar in $\mathrm{EC}_{50}$ and maximal activity to $\alpha$-phenyl- $N$-tert-butylnitrone (PBN) and less potent than any of HBNs 4-6. The results of neuroprotection in an in vitro oxygen glucose deprivation model showed that HTN2 was the most powerful $\left(\mathrm{EC}_{50}=87.57 \pm 3.87 \mu \mathrm{M}\right)$, at lower dose, but 50 -fold higher than its analogous HBN5, and $\approx 1.7$-fold less potent than PBN. HTN3 had a very good antinecrotic $\left(\mathrm{IC}_{50}=3.47 \pm 0.57 \mu \mathrm{M}\right)$, antiapoptotic, and antioxidant $\left(\mathrm{EC}_{50}=6.77 \pm 1.35 \mu \mathrm{M}\right)$ profile, very similar to that of its analogous HBN6. In spite of these results, and still being attractive neuroprotective agents, HTNs 2 and 3 do not have better neuroprotective properties than HBN6, but clearly exceed that of PBN.
\end{abstract}

Keywords: antioxidants; free radical scavengers; homo-tris-nitrones; neuroprotection; nitrones; oligomycin A/rotenone; oxygen-glucose-deprivation model; $\alpha$-phenyl- $\mathrm{N}$-tert-butylnitrone; synthesis

\section{Introduction}

Nowadays it is largely accepted that reactive oxygen species (ROS), such as $\mathrm{O}_{2}^{-\bullet}, \mathrm{HO}^{\bullet}, \mathrm{HO}_{2}{ }^{\bullet}$, are one of the main biological factors involved in the etiology of a number of pathologies such 
as neurodegenerative and psychiatric disorders, or stroke, playing key roles in their pathogenesis, suggesting thus possible therapeutic interventions [1-3]. Consequently, the identification of new antioxidants, and the development of more potent analogues are under extensive research [4].

Stroke is a major public health problem, whose current clinical treatment, based on treatment with recombinant tissue plasminogen activator is hampered by important side effects and narrow therapeutic window [5]. Thus, there is an urgent need for more effective therapies. This is the reason, combined to the multifactorial nature of this pathology, of the increased and continued attention that has been devoted to the research for new and more effective ROS trapping agents [6].

Nitrones, well known antioxidant organic molecules widely used as radical traps, appear to be interesting drug candidates to treat stroke [7-19]. The first proposal of nitrones as therapeutic candidates for stroke was made by Novelli, who reported that $\alpha$-phenyl $N$-tert-butylnitrone (PBN) (Figure 1) prevented and reversed traumatic shock injury in rats [20]. Thus, not surprisingly, the search for new nitrones continue to attract the interest of a number of laboratories around the world [21-33]. This has been the case of our group, that in the last decade has been very active in this area reporting new antioxidant nitrones for the potential stroke therapy [34-38].

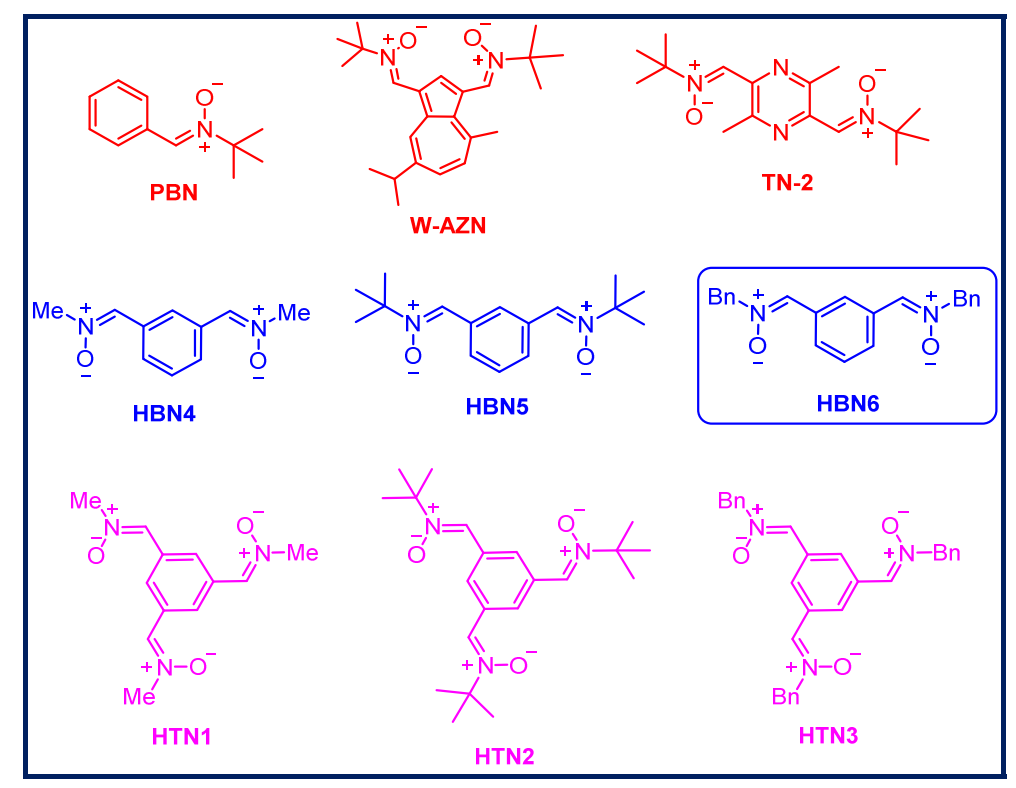

Figure 1. Structures of $\alpha$-phenyl-N-tert-butylnitrone (PBN), W-AZN, TN-2 (red), homo-bis-nitrones (HBNs 4-6) (blue), and homo-tris-nitrones (HTNs 1-3) (pink).

In this field, the neuroprotective profile and strong antioxidant capacity of bis-nitrones, as well as their potential clinical applications for the therapy of stroke has been documented in the literature, showing very promising hit-azulenyl nitrones [39-41] such as bis-nitrone W-AZN (Figure 1), of particular interest due to its neuroprotective power in an in vivo model of stroke [42], or bis-nitrone TN-2 (Figure 1), an excellent example of a compound bearing two tert-butyl nitrone groups, bound to a pyrazine heterocyclic nucleus, with remarkable neuroprotective capacity most possibly due to its ability to trap toxic ROS [43-45].

Our group has recently described a number of homo-bis-nitrones (HBNs) derived from PBN, from which HBN6 (Figure 1) exhibited a potent neuroprotective effect in in vitro and in vivo ischemia models, a very good antinecrotic and antiapoptotic activity, as well as very good antioxidant properties, stronger than the parent PBN [46]. Thus, our previous results strongly suggest that HBN6 is a potential neuroprotective agent against stroke and that the introduction of two nitrone groups improves the neuroprotective properties of PBN-based nitrone containing only one nitrone group [46]. Now, and continuing with our interest of polynitrones for stroke, and based on these previously reported 
results [46], we wondered whether the incorporation of a third nitrone motif would result in an improved and stronger neuroprotection effect. Consequently, we designed symmetrically substituted homo-tris-nitrones (HTNs) resulting in nitrones HTNs 1-3 (Figure 1).

\section{Results and Discussion}

\subsection{Chemistry}

The synthesis of HTNs 1-3 was carried out as shown in Scheme 1 starting form benzene-1,3,5tricarbaldehyde, and readily available $N$-alkylhydroxylamine hydrochlorides were selected. All the nitrones were isolated as pure and single $\mathrm{Z}$ isomers at the double $\operatorname{ArC}(\mathrm{H})=\mathrm{N}^{+}\left(\mathrm{O}^{-}\right) \mathrm{R}$ bond, and gave analytical and spectroscopic data in good agreement with their structures (see Materials and Methods, Supplementary Material). Only HTN2 (Figure 1) has been previously described [47,48] in studies connected with the synthesis and magnetic properties of stable nitroxyl tri-radicals [47], and as spin trapping agents for the treatment of diseases associated with oxidation of lipids and proteins [48]. According to our design, and taking into account the structure if HBN6 as reference, HTNs 1-3 all bear the nitrone motives in relative meta position, a choice that was favored by the readily, commercially available benzene-1,3,5-tricarbaldehyde precursor, HTN1, HTN2, and HTN3 (Figure 1) bearing a $\mathrm{N}$-methyl, a $\mathrm{N}$-tert-butyl, and a $\mathrm{N}$-benzyl group, respectively, at the $\mathrm{R}$ nitrone functional group.

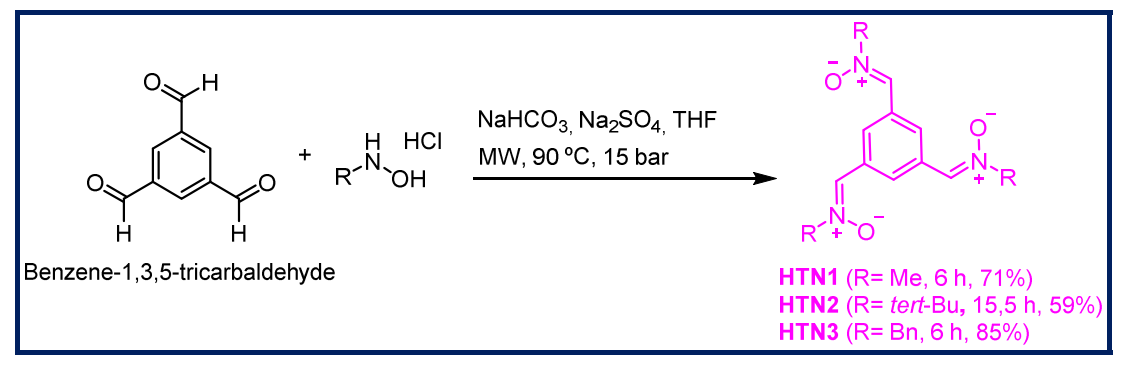

Scheme 1. Synthesis of HTNs 1-3.

\subsection{Neuroprotection Studies of HTNs 1-3}

\subsubsection{Neuroprotection Analysis in an Oligomycin A/Rotenone Model}

One of the first events that take place in the initial stages of stroke is the collapse of the mitochondrial electron transport chain, leading to extended cell death and brain damage, due to the formation of ROS. In order to mimic this event into suitable experiments, we tested the effect of the new nitrones on cell death induced by the neurotoxic combination of oligomycin $A$ /rotenone $(O / R)$, inhibitors of mitochondrial complexes V and I, respectively. Based on a previous work from our laboratory [46], we selected the appropriate experimental conditions, and tested the neuroprotective effect of HTNs 1-3 at different concentrations (1-1000 $\mu \mathrm{M})$, adding them $10 \mathrm{~min}$ before the administration of $\mathrm{O} 10 \mu \mathrm{M} / \mathrm{R} 30 \mu \mathrm{M}$, and using PBN and N-acetyl-L-cysteine (NAC) as reference compounds [46].

With pure nitrones HTNs 1-3 in hand, we next investigated in depth their neuroprotective capacity according to the usual experimental protocols (see Materials and Methods) [49-52].

As shown in Figure 2A, HTNs 1-3 showed a clear effect increasing cell viability in a concentration-dependent manner. The nitrone that provided the best result was HTN3, since from very low concentrations $(10 \mu \mathrm{M})$ achieves a viability value above $70 \%$, and even at high concentrations exceeds the viability of the control. HTN1, at low concentrations $(1 \mu \mathrm{M})$, provided more than $60 \%$ viability, although like HTN2, failed to reach the maximal cell viability observed for HTN3 at high concentrations. In general, among the HTNs we could not observe high significant differences, but all of them improve the data obtained for the reference nitrone, PBN. Regarding neuroprotection, it was observed that the neuroprotective effects of HTNs were clearly concentration dependent (Figure 2B). 
To assess more accurately the differences in neuroprotective capacity of these nitrones, a study of the $\mathrm{EC}_{50}$ was carried out (Table 1). The order of neuroprotective potency of the compounds (from lowest to highest $\mathrm{EC}_{50}$ ) was HTN2 $\geq \mathbf{P B N} \geq \mathbf{H T N} 3 \geq \mathbf{H T N 1}$ (Table 1). However, the maximal activity (\%) data reflect a different trend (from highest to lowest): HTN3 $\geq$ HTN1 $\geq$ PBN $\geq$ HTN2. This means that the best compound that produces neuroprotection at a lower dose is HTN2, bearing a N-tert-Bu substituent; while the compound that produces a greater neuroprotection, although at a higher dose, is HTN3, bearing a N-Bn substituent. HTN1, bearing a N-Me substituent, would have an intermediate capacity between its analogues HTN2 and HTN3. HTN2 is similar in $\mathrm{EC}_{50}$ and maximal activity to PBN. However, the $\mathrm{EC}_{50 \text { s }}$ of these HTNs were higher than their corresponding HBNs 4-6 [46] (Table 1), which indicates that, having a similar maximum activity, HTNs showed less neuroprotective capacity than their structurally corresponding HBNs 4-6 [46] and NAC [46]. Therefore, we conclude that the introduction of an additional nitrone group seemed not to provide an additional benefit to the neuroprotective activity observed for HBNs 4-6, bearing two nitrone groups.
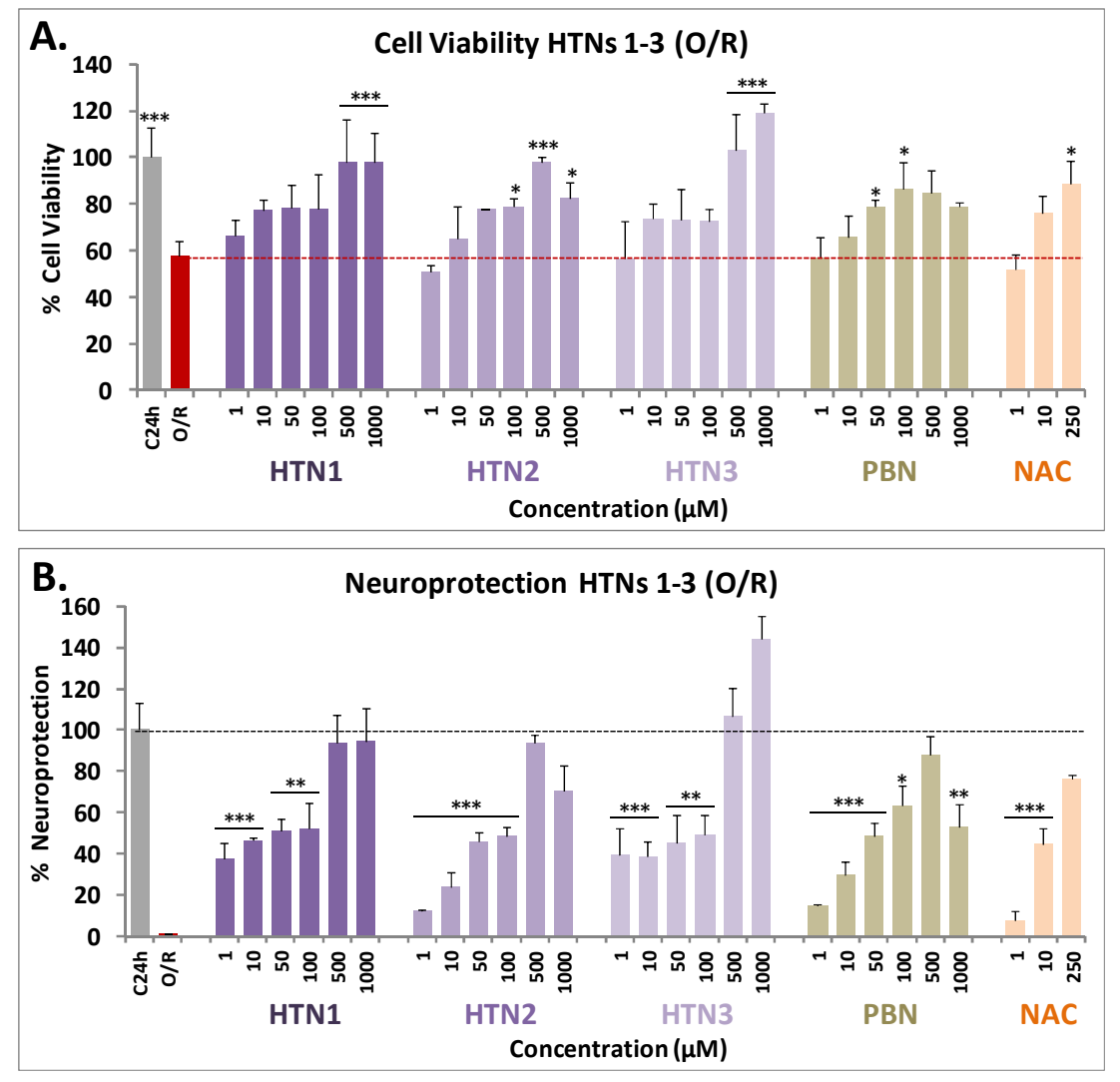

Figure 2. Neuroprotective effect of HTNs 1-3 on SH-SY5Y human neuroblastoma metabolic activity after treatment with oligomycin A $10 \mu \mathrm{M} /$ rotenone $30 \mu \mathrm{M}$ (O/R). (A) Bars show \% cell viability after treatment with $\mathrm{O} / \mathrm{R}$, with, or without, HBNs, PBN, and NAC, at the indicated concentrations. (B) Bars show \% of the resulting neuroprotection at the same concentrations, considering as $100 \%$ neuroprotection the difference between the control (C24h) viability and the obtained in the presence of O/R. Values are the mean \pm SEM of three experiments, each one performed in triplicate. The statistics in (A) compare differences with $\mathrm{O} / \mathrm{R}$ (red dotted line) and the statistics in (B) compare differences with control (100\% neuroprotection without nitrones) (C24h) (black dotted line) at ${ }^{*} p<0.05,{ }^{* *} p<0.01$, and ${ }^{* * *} p<0.001$ (one-way ANOVA, followed by Holm-Sidak analysis as a test post hoc). No statistic comparisons are shown for values higher than those for $\mathrm{C}$. 
Table 1. Neuroprotective effect of HTNs 1-3, PBN, and NAC against neurotoxicity induced by oligomycin $\mathrm{A} /$ rotenone in human neuroblastoma SH-SY5Y cells.

\begin{tabular}{|c|c|c|c|c|c|c|c|c|}
\hline \multirow{4}{*}{ 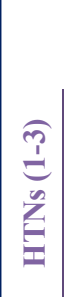 } & Compound & $\begin{array}{l}\text { Structure } \\
\text { (R) }\end{array}$ & $\begin{array}{c}\text { Neuroprotection } \\
\text { EC }_{50} \pm \operatorname{SEM}(\mu \mathrm{M})\end{array}$ & $\begin{array}{c}\text { P } \\
(\text { PBN })\end{array}$ & $\begin{array}{c}\mathrm{P}< \\
\text { (HTN2) }\end{array}$ & $\begin{array}{l}\text { Maximal Activity } \\
\text { mean } \pm \text { SEM }(\%)\end{array}$ & $\begin{array}{c}\text { P }< \\
(\text { PBN })\end{array}$ & $\begin{array}{c}\text { P }< \\
(\text { HTN2) }\end{array}$ \\
\hline & HTN1 & Me & $89.17 \pm 7.59$ & ns & * & $94.56 \pm 9.21$ & ns & ns \\
\hline & HTN2 & tert-Bu & $51.63 \pm 4.32$ & * & - & $83.45 \pm 3.54$ & ns & - \\
\hline & HTN3 & Bn & $79.50 \pm 7.49$ & ns & $* * *$ & $125.57 \pm 6.19$ & $* *$ & $* * *$ \\
\hline \multirow{5}{*}{ 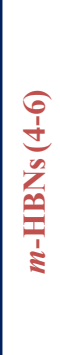 } & PBN & - & $65.63 \pm 6.89$ & - & ns & $88.18 \pm 5.20$ & - & ns \\
\hline & HBN4 & Me & $16.56 \pm 3.33^{[46]}$ & $* * *$ & $* * *$ & $118.05 \pm 8.19^{[46]}$ & $* *$ & $* *$ \\
\hline & HBN5 & tert-Bu & $4.15 \pm 1.48^{[46]}$ & $* * *$ & $* * *$ & $108.56 \pm 7.42^{[46]}$ & $* *$ & * \\
\hline & HBN6 & Bn & $5.56 \pm 1.09^{[46]}$ & $* * *$ & $* * *$ & $136.17 \pm 6.64^{[46]}$ & $* * *$ & $* * *$ \\
\hline & NAC & - & $5.16 \pm 1.60^{[46]}$ & $* * *$ & $* * *$ & $113.39 \pm 5.87^{[46]}$ & $* *$ & $* *$ \\
\hline
\end{tabular}

The estimation of $\mathrm{EC}_{50}(\mu \mathrm{M})$ and maximal activities (\% neuroprotection) values were performed by a weighted nonlinear regression of minimum squares using logistic curves, as is described in the "Statistical Analysis" section of "Neuroprotection Assessment Assays". Values are the mean \pm S.E.M. Data analysis was carried out with SigmaPlot v.12., and ANOVA one-way to get the significant statistics of HTNs with respect to PBN. Differences are statistically significant when $p \leq 0.05$. Differences are statistically significant when $p \leq 0.05$. ${ }^{*} p<0.05,{ }^{* *} p<0.01$, and ${ }^{* * *} p<0.001$, $\mathrm{ns}=$ non-significant (ANOVA one-way, followed by Holm-Sidak analysis as test post hoc).

\subsubsection{Neuroprotection Analysis in an Oxygen Glucose Deprivation Model}

The neuroprotective effect of HTNs 1-3 was next evaluated in an in vitro oxygen glucose deprivation (OGD) model, followed by ischemic reperfusion (IR) by using XTT cell viability test, a colorimetric assay that detects the cellular metabolic activities, at concentrations from 0.01 to $1000 \mu \mathrm{M}$, after IR. After OGD (I) (4 h), 50-80\% cell death was observed, showing a small cell recovery after $24 \mathrm{~h}$ IR of 38-61\% (49.29 \pm 3.26 ; mean \pm SEM; $n=16)$. As shown in Figure 3, all HTNs 1-3 were able to partially or totally reverse cell death induced by IR, in a concentration dependent manner.

Based on these results, next we carried out the analyses of concentration-response curves for all the HTNs, PBN, and NAC, in the 0.00001 and $1 \mathrm{mM}$ range, taking into account the potential neurotoxic effect at high concentrations, as measured in the basal neurotoxicity section (see below). As a result, we determined the $\mathrm{EC}_{50}$ and the highest neuroprotective activities for HTNs 1-3, and PBN. As shown in Table 2, nitrones HTNs 1-3 were less potent neuroprotective agents than PBN, as they showed significantly higher $\mathrm{EC}_{50}$ values, although they exhibited higher neuroprotective activity than PBN at higher concentrations. Thus, the order of neuroprotective power (from lowest to highest $E_{50}$ ) was $\mathbf{P B N} \geq \mathbf{H T N} 2 \geq \mathbf{H T N} 3 \geq \mathbf{H T N} 1$ (Table 2). In this case, there was only a small significant difference between the $\mathrm{EC}_{50}$ values of HTN2 and HTN1, but there were no significant differences between the \% of maximal neuroprotective activities among the HTNs 1-3. However, like in the neuroprotection against $\mathrm{O} / \mathrm{R}$, the $\mathrm{EC}_{50 \text { s }}$ values of these HTNs were higher than their corresponding HBNs 4-6 and NAC, having a similar maximal activity [46] (Table 2), which indicates that, in this case too, the introduction of a third nitrone group, does not provide a better neuroprotective capacity with respect to their structurally similar HBNs. Thus, from the structure activity relationship (SAR) point of view, note that the incorporation of a new nitrone group in HTNs 1-3 with respect to HBN4-6 [46], significantly decreased their neuroprotective capacity. 


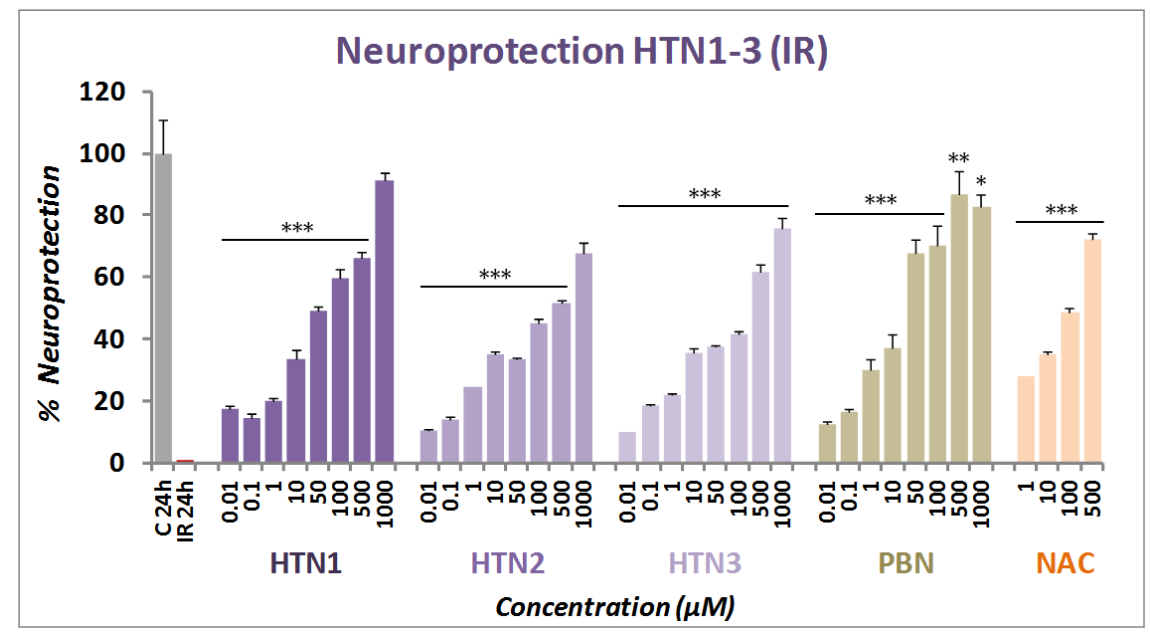

Figure 3. Neuroprotective effect of HTNs 1-3 on neuroblastoma cell viability after oxygen glucose deprivation $(4 \mathrm{~h})$ and ischemic reperfusion $(24 \mathrm{~h})(\mathrm{IR})$. Bars show \% neuroprotection at indicated concentrations, considering $100 \%$ neuroprotection the difference in viability between Control $\left(\mathrm{C}_{24 \mathrm{~h}}\right)$ and IR alone. Values represent the mean \pm SEM after three experiments, each one in triplicate. The statistics compare the effect of each HTN concentration with 100\% neuroprotection, without IR (C 24h) at ${ }^{*} p<0.05,{ }^{* *} p<0.01$, and ${ }^{* *} p<0.001$ (ANOVA one-way, followed by Holm-Sidak analysis as test post hoc).

Table 2. Neuroprotective effect of HTNs 1-3, PBN, and NAC after oxygen glucose deprivation/ischemic reperfusion (IR) in human neuroblastoma SH-SY5Y cells.

\begin{tabular}{|c|c|c|c|c|c|c|c|c|}
\hline \multirow{4}{*}{ 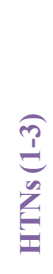 } & Compound & $\begin{array}{l}\text { Structure } \\
\text { (R) }\end{array}$ & $\begin{array}{l}\text { Neuroprotection } \\
\mathrm{EC}_{50} \pm \operatorname{SEM}(\mu \mathrm{M})\end{array}$ & $\begin{array}{c}\mathbf{P}< \\
(\mathbf{P B N})\end{array}$ & $\begin{array}{c}\mathbf{P}< \\
(\text { HTN2) }\end{array}$ & $\begin{array}{l}\text { Maximal Activity } \\
\text { mean } \pm \text { SEM }(\%)\end{array}$ & $\begin{array}{c}\mathbf{P}< \\
(\mathbf{P B N})\end{array}$ & $\begin{array}{c}\text { P< } \\
(\text { HTN2) }\end{array}$ \\
\hline & HTN1 & Me & $108.06 \pm 5.94$ & $* * *$ & * & $96.59 \pm 6.82$ & ns & ns \\
\hline & HTN2 & tert-Bu & $87.57 \pm 3,87$ & $* *$ & - & $115.54 \pm 6.73$ & * & - \\
\hline & HTN3 & Bn & $98.14 \pm 4.87$ & $* *$ & ns & $124.06 \pm 7.40$ & $* *$ & ns \\
\hline \multirow{5}{*}{ 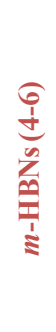 } & PBN & - & $51.13 \pm 6.37$ & - & $* *$ & $86.32 \pm 7.18$ & - & * \\
\hline & HBN4 & Me & $38.85 \pm 4.05^{[46]}$ & ns & $* * *$ & $78.21 \pm 2.23^{|46|}$ & ns & $* *$ \\
\hline & HBN5 & tert-Bu & $1.70 \pm 0.18^{[46]}$ & $* * *$ & $* * *$ & $113.31 \pm 4.69^{[46]}$ & $* *$ & ns \\
\hline & HBN6 & Bn & $1.24 \pm 0.23^{[46]}$ & $* * *$ & $* * *$ & $104.07 \pm 3.06^{[46]}$ & * & ns \\
\hline & NAC & - & $2.58 \pm 0.91^{[46]}$ & $* * *$ & $* * *$ & $110.30 \pm 2.81^{[46]}$ & $* *$ & ns \\
\hline
\end{tabular}

The estimation of $\mathrm{EC}_{50}(\mu \mathrm{M})$ and maximal activities (\% neuroprotection) values were performed by a weighted nonlinear regression of minimum squares using logistic curves, as is described in the "Statistical Analysis" section of "Neuroprotection Assessment Assays". Values are the mean \pm S.E.M. Data analysis was carried out with SigmaPlot v.12., and ANOVA one-way to get the significant statistics of HTNs and HBNs with respect to PBN and HTN2. Differences are statistically significant when $p \leq 0.05$. ${ }^{*} p<0.05$, ${ }^{* *} p<0.01$, and ${ }^{* * *} p<0.001$, ns $=$ non-significant (ANOVA one-way, followed by Holm-Sidak analysis as test post hoc).

\subsubsection{Effect of HTNs on Necrotic and Apoptotic Cell Death Induced by Induced by Oxygen} Glucose Deprivation

During an ischemic stroke, in the brain area affected there is massive cell death due to necrosis, and as a consequence, the plasma membrane is broken or significantly permeabilized. Under these circumstances, lactate dehydrogenase (LDH), a soluble cytosolic enzyme, easily crosses the damaged 
membrane, and by measuring its extracellular activity, and comparing it with its intracellular activity, it is possible to determine the extent of the cell necrosis that took place in the OGD experiment.

As shown in Figure 4, from the values obtained from the measurement of the LDH release after OGD for $4 \mathrm{~h}$ followed by $24 \mathrm{~h}$ IR, on neuroblastoma cells, by adding the HTNs, PBN, and NAC, at 1-1000 $\mu \mathrm{M}$ concentrations, we concluded that the more efficient was HTN3, followed by HTN2 and HTN1 (Figure 4).

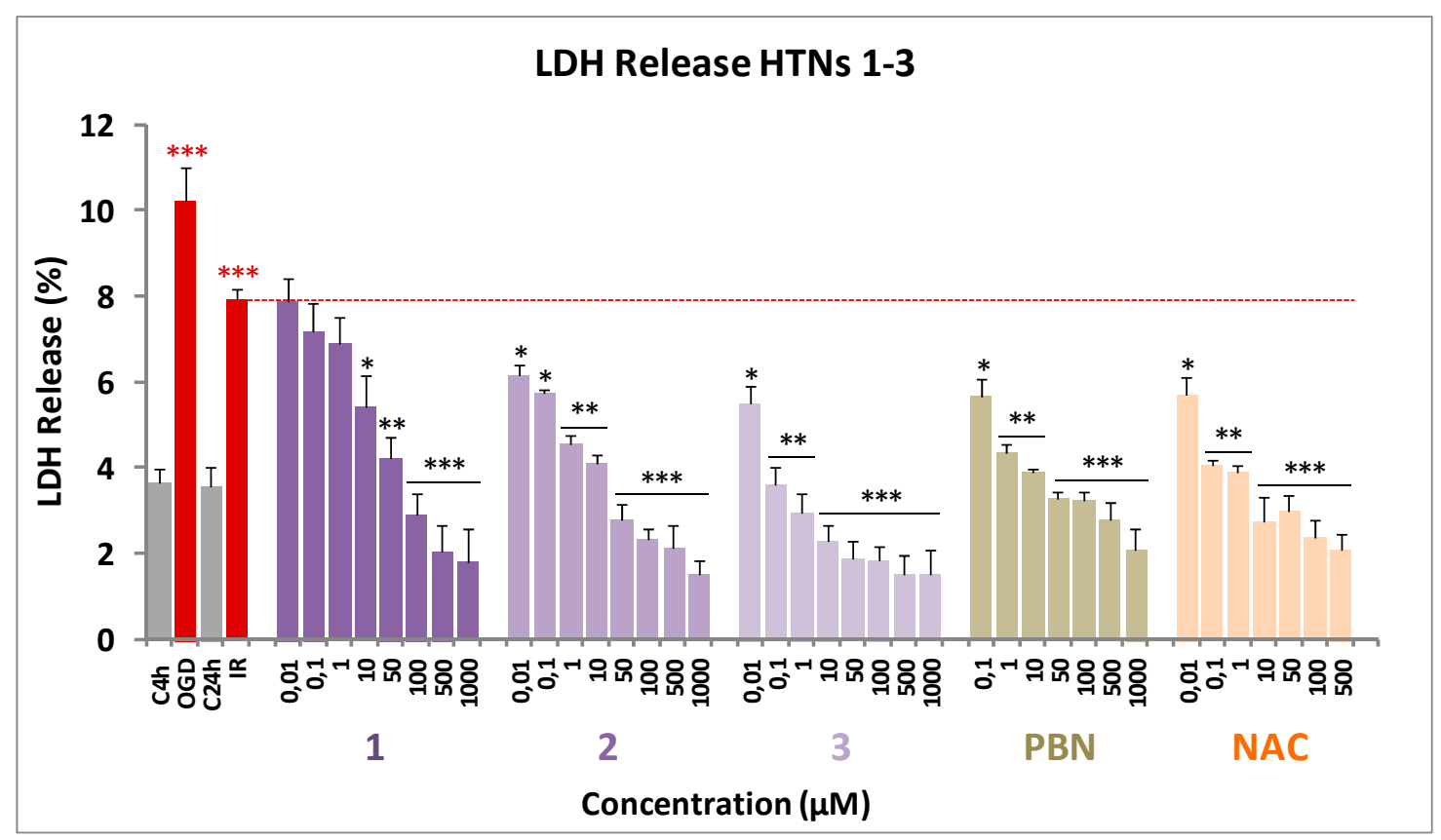

Figure 4. Effect of HTNs 1-3 on the lactate dehydrogenase release in SH-SY5Y cells after ischemia reperfusion. Bars show \% LDH release after OGD $(4 \mathrm{~h})$ and IR $(24 \mathrm{~h})$, without treatment (IR $24 \mathrm{~h}$ ) or treated with HTNs 1-3, PBN, and NAC, at the indicated concentrations. Values are the mean \pm SEM of three experiments, each one performed in triplicate, and compared to the effect of I and IR on respective controls (red ${ }^{* * *}$ ) or the effect of the different compounds after IR ( $24 \mathrm{~h}$ ) with IR (24 h) alone (red dotted line) in the absence of these compounds (black ${ }^{* * *}$ ). Data were statistically analyzed by one-way ANOVA, followed by Holm-Sidak as test post hoc. ${ }^{*} p<0.05,{ }^{* *} p<0.01$, and ${ }^{* * *} p<0.001$.

These data were confirmed by the calculation of the $\mathrm{IC}_{50}$ and the maximal activities (Table 3). In this case, HTNs 1-3 showed similar maximal activity; so, their efficiency was compared using the $\mathrm{IC}_{50}$ values.

According to the results in Table 3 HTN3 exhibits higher antinecrotic power (lower $\mathrm{IC}_{50}$ ) than HTN2, followed by HTN1, which had the lowest antinecrotic power of the tested HTNs. Comparing with the standards, HTN3 is significantly 10- and 6-fold more potent than PBN and NAC, respectively.

Next, and in order to evaluate the extent of cell death by apoptosis, we determined the caspase- 3 activity, by using DEVD-AMC as substrate, that when hydrolyzed affords fluorescent AMC. Therefore, after OGD ( $4 \mathrm{~h}$ ), and adding HTNs 1-3, PBN, and NAC, at 1-250 $\mu \mathrm{M}$ concentration doses, followed by IR $(24 \mathrm{~h})$, the cells were lysated, DEVD-AMC was added, and the fluorescence measured.

As shown from the values in Figure 5, and regarding antiapoptotic effects, compound HTN3 was undoubtedly the most potent of the three HTNs, even more active than its homologous HBN6 [46]. Thus, we can conclude that the $N$-Bn group provides antiapoptotic activity to these nitrones. Finally, as it was the case with their antinecrotic capacity, HTN3 was significantly higher than that of PBN, while the antiapoptotic activity of HTN1 was similar, and not significantly different, than that of the reference nitrone. 
Table 3. Effect of HTNs 1-3, PBN, and NAC on the lactate dehydrogenase release after oxygen glucose deprivation/ischemic reperfusion in human neuroblastoma SH-SY5Y cells. EC 50 and maximal activities.

\begin{tabular}{|c|c|c|c|c|c|c|c|c|}
\hline \multirow{6}{*}{ 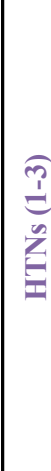 } & Compound & $\mathbf{R}$ & $\begin{array}{c}\text { LDH Release } \\
\text { Inhibition } \\
\text { IC }_{50} \pm \text { SEM }(\mu \mathrm{M})\end{array}$ & $\begin{array}{c}\mathbf{P}< \\
(\mathbf{P B N})\end{array}$ & $\begin{array}{c}\text { P }< \\
(\text { HTN2) }\end{array}$ & $\begin{array}{r}\text { Maximal Inhibition } \\
\text { mean } \pm \text { SEM }(\%)\end{array}$ & $\begin{array}{c}\mathrm{P}< \\
(\mathbf{P B N})\end{array}$ & $\begin{array}{c}\text { P< } \\
(\text { HTN2) }\end{array}$ \\
\hline & HTN1 & Me & $23.34 \pm 7.71$ & ns & $* *$ & $82.95 \pm 7.88$ & ns & ns \\
\hline & HTN2 & tert-Bu & $8.49 \pm 2.45$ & $* * *$ & - & $85.21 \pm 10.69$ & ns & - \\
\hline & HTN3 & Bn & $3.47 \pm 0.57$ & $* * *$ & ns & $82.47 \pm 12.64$ & ns & ns \\
\hline & PBN & - & $32.01 \pm 8.61$ & - & $* * *$ & $89.27 \pm 11.41$ & - & ns \\
\hline & NAC & - & $13.21 \pm 5.49$ & $* *$ & ns & $95.60 \pm 11.05$ & ns & ns \\
\hline
\end{tabular}

The estimation of $\mathrm{IC}_{50}(\mu \mathrm{M})$ and maximal inhibitory activities (\%) values were performed by a weighted nonlinear regression of minimum squares using logistic curves, as is described in the "Statistical Analysis" section of "Neuroprotection Assessment Assays". Values are the mean \pm S.E.M. Data analysis was carried out with SigmaPlot v.12., and ANOVA one-way to get the significant statistics of HTNs with respect to PBN, or to HTN2. Differences are statistically significant when $p<0.05,{ }^{* *} p<0.01,{ }^{* *} p<0.001$. ns $=$ non-significant (ANOVA one-way, followed by Holm-Sidak analysis as test post hoc).

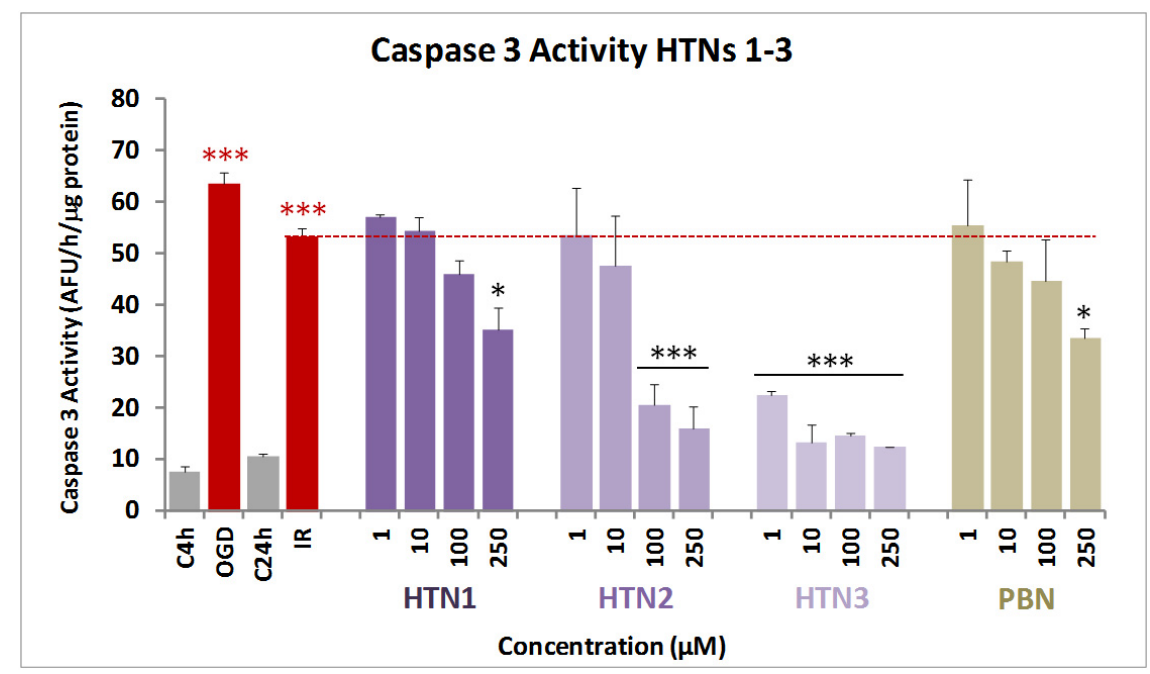

Figure 5. Effect of HTNs 1-3 on caspase-3 activity in SH-SY5Y neuroblastoma cells after ischemia reperfusion. Bars show \% LDH release after OGD (4 h) and IR (24 h), without treatment (IR alone) or treated with HTNs 1-3, PBN, and NAC, at the indicated concentrations. Values are the mean \pm SEM of three experiments, each one performed in triplicate, and compared to the effect of I and IR on respective controls (red ${ }^{* * *}$ ) or the effect of the different compounds after IR ( $24 \mathrm{~h}$ ) with IR alone (red dotted line), in the absence of these compounds (black ${ }^{* * *}$ ). Data were statistically analyzed by one-way ANOVA, followed by Holm-Sidak as test post hoc. ${ }^{*} p<0.05,{ }^{* *} p<0.01$, and ${ }^{* *} p<0.001$. UAF $=$ arbitrary fluorescent units.

\subsubsection{Basal Neurotoxicity of HTNs 1-3}

Based on the results described above, the analysis of the possible neurotoxicity of the HTNs 1-3 was mandatory. Thus, an experiment was carried out by measuring the cell viability with XTT, but without adding any toxic insult. As shown in Figure 6, HTN1-3, as well as PBN and NAC, did not show any neurotoxic effect at basal level. 


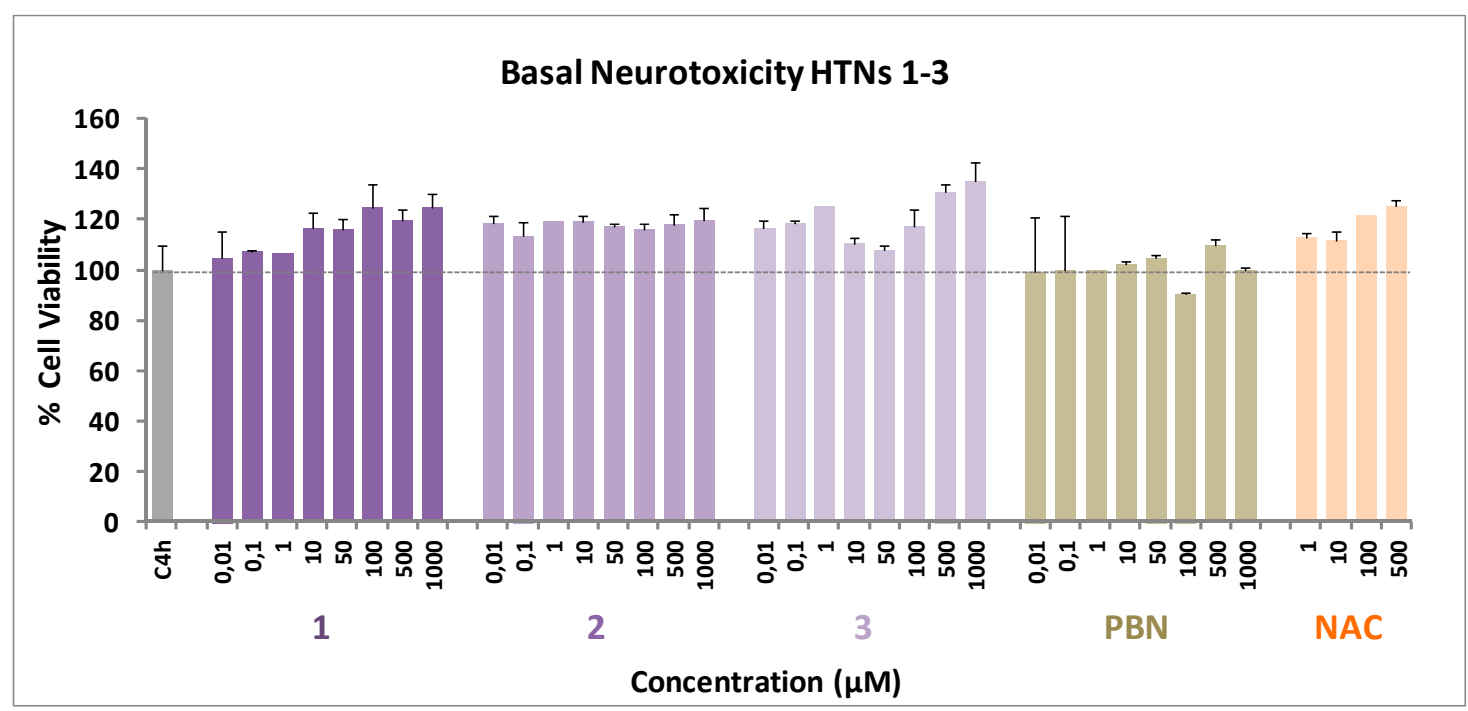

Figure 6. Effect of HTNs 1-3, PBN, and NAC on human neuroblastoma SH-SY5Y cell viability under basal conditions. Bars represent \% of cell viability in the presence of the ligands at the indicated concentrations. Cell viability for the untreated cells (C4h) was assigned 100\% (100 $\pm 5.52 \%)$. Values are the mean \pm SEM of five experiments, each one in triplicate. No statistically significant differences were observed between the control (black dotted line) and the different nitrones tested at the concentrations indicated (one-way ANOVA test).

2.2.5. Antioxidant Capacity of HTNs 1-3. Production and Scavenging of Radical Superoxide Radical in Human Neuroblastoma SH-SY5Y Cells

The results shown in the previous sections prompted us to investigate whether the observed neuroprotection due to HTNs 1-3 was a consequence of their capacity to act as antioxidants, and ROS scavengers, particularly of superoxide anion-radical $\left(\mathrm{O}_{2}{ }^{-\lambda}\right)$, whose detection can be carried out by using dihydroethidium (DHE), after OGD (3 h) and IR (3 h), with, or without HTNs 1-3, including PBN as a reference.

As shown in Figure 7, ROS level production after IR was higher than ROS production after OGD alone. As expected, PBN was a middle ROS trapping agent compared to the tested nitrones. Thus, in general, the HTNs 1-3 showed an excellent antioxidant profile, the most potent being HTNs 2 and 3, with an antioxidant profile similar to their counterparts HBN5 and 6, [46] greatly exceeding the antioxidant power of PBN.

The analyses of concentration-response curves and calculations of $\mathrm{EC}_{50}$ and the highest antioxidant activities for HTNs 1-3, PBN, and NAC are shown in Table 4. The EC 50 values, from the lowest to the highest, follows the order: NAC $\leq$ HTN2 $\leq$ HTN3 $<$ PBN $<$ HTN1. As the highest antioxidant activity (maximal activities) was lower for HTN1 and PBN and higher for HTNs 2, 3, and NAC, we conclude that, regarding the antioxidant capacity against IR-induced superoxide production, HTN2 exhibit the best antioxidant properties, which was very similar to the antioxidant capacity of its HBNs $\mathbf{5}$ and $\mathbf{6}$ counterparts [46], as well as that of NAC (Table 4).

In summary, and from the SAR point of view, once again HTN2 and HTN3, bearing $N$-tert-Bu and $N$-Bn, substituents, respectively, were confirmed to be the most potent HTNs, with antioxidant capacity similar to their analogous HBNs 5 and 6, and to NAC, and better than that of PBN. 


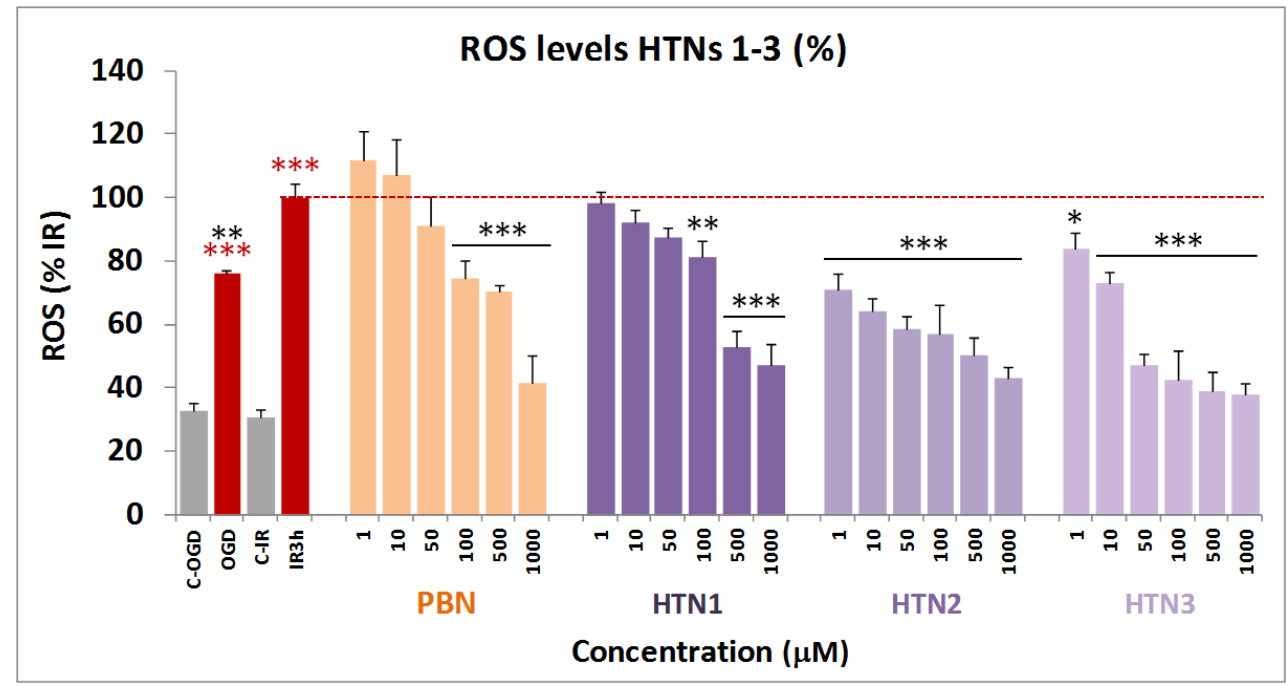

Figure 7. Inhibitory effects of HTNs 1-3, and PBN on ROS (superoxide) production in SHSY5Y human neuroblastoma cell cultures exposed to oxygen glucose deprivation $(4 \mathrm{~h})$ and ischemic reperfusion ( $3 \mathrm{~h}$ ). Bars shows \% ROS formed after OGD and IR alone (IR $3 \mathrm{~h}$ ) or after treatment with HTNs 1-3 and $\mathrm{PBN}$, at the indicated concentration concentrations. Values are then mean \pm SEM of three experiments, each one performed in triplicate. Values for ROS in IR were calculated as $1.98 \pm 0.25 \mathrm{UAF} / \mathrm{min} / 150,000$ cells. The statistics compare the effect of IR against the corresponding control (red ${ }^{* *}$ ) or the effect of the different compounds respect to IR alone (red dotted line), (black ${ }^{* *}$ ) at ${ }^{*} p<0.05,{ }^{* *} p<0.01$, *** $p<0.001$ (one-way ANOVA followed by Holm-Sidak analysis post hoc).

Table 4. Antioxidant effect of HTNs 1-3, PBN, and NAC after oxygen glucose deprivation/ischemia reperfusion in human neuroblastoma SH-SY5Y cells.

\begin{tabular}{|c|c|c|c|c|c|c|c|}
\hline Compound & $\begin{array}{l}\text { Structure } \\
\text { (R) }\end{array}$ & $\begin{array}{c}\text { Antioxidant } \\
\text { effect } \\
\mathrm{EC}_{50} \pm \mathrm{SEM} \\
(\mu \mathrm{M})\end{array}$ & $\begin{array}{c}\mathbf{P}< \\
(\mathbf{P B N})\end{array}$ & $\begin{array}{c}\text { P< } \\
(\text { HTN2) }\end{array}$ & $\begin{array}{l}\text { Maximal Activity } \\
(\text { mean } \pm \text { SEM) } \%\end{array}$ & $\begin{array}{c}\mathbf{P}< \\
(\mathbf{P B N})\end{array}$ & $\begin{array}{c}\text { P< } \\
(\text { HBN2) }\end{array}$ \\
\hline HTN1 & Me & $66.61 \pm 5.46$ & $* * *$ & $* * *$ & $80.43 \pm 4.02$ & ns & $* *$ \\
\hline HTN2 & tert-Bu & $5.12 \pm 1.23$ & $* * *$ & - & $93.63 \pm 5.64$ & * & - \\
\hline HTN3 & Bn & $6.77 \pm 1.35$ & $* * *$ & ns & $90.95 \pm 2.67$ & * & ns \\
\hline HBN4 & Me & $3.31 \pm 0.99^{[46]}$ & $* * *$ & $* *$ & $61.38 \pm 2.85^{[46]}$ & $* *$ & $* * *$ \\
\hline HBN5 & tert-Bu & $6.73 \pm 0.57^{[46]}$ & $* * *$ & $*$ & $96.65 \pm 7.38^{[46]}$ & ** & ns \\
\hline HBN6 & Bn & $5.91 \pm 1.09^{[46]}$ & $* * *$ & * & $118.19 \pm 3.65^{[46]}$ & $* * *$ & $* *$ \\
\hline PBN & - & $23.96 \pm 5.21$ & - & $* * *$ & $81.53 \pm 4.09$ & - & * \\
\hline NAC & - & $3.23 \pm 0.35^{[46]}$ & $* * *$ & ns & $112.35 \pm 3.32^{[46]}$ & $* * *$ & $* *$ \\
\hline
\end{tabular}

The estimation of $\mathrm{EC}_{50}(\mu \mathrm{M})$ and maximal activities (\% antioxidant effect) values were performed by a weighted nonlinear regression of minimum squares using logistic curves, as is described in the "Statistical Analysis" section of "Neuroprotection Assessment Assays". Values are the mean \pm S.E.M. $\mathrm{EC}_{50}$ and maximal activities were calculated from the data obtained from three experiments, each one in triplicate. The statistics compare differences with PBN or HTN2 at ${ }^{*} p<0.05,{ }^{* *} p<0.01$, and ${ }^{* * *} p<0.001$ and ns = non-significant (one-way ANOVA, followed by Holm-Sidak analysis as a test post hoc). 


\subsection{Antioxidant Tests}

Based on the in vitro neuroprotection results, we carried out the antioxidant power analysis of HTNs 1-3, on diverse antioxidant tests [53], using NDGA and Trolox as standards for comparative purposes. As shown in Table 5, HTN3 was able to inhibit 92\% LP, in the same range as Trolox (88\%), in the same experiment, as well as LOX $(70 \mu \mathrm{M})$ and $\mathrm{ABTS}^{+\cdot}(10 \%)$, albeit to a poorer extent than NDGA $(0.45 \mu \mathrm{M})$, and Trolox $(91 \%)$, respectively. HTN2 also has a good antioxidant profile, although weaker than HTN3, as it was only able to inhibit $55 \%$ LP, as well as LOX $(26 \%)$, but not (ABTS ${ }^{+}$). However, HTN3 and HTN2 were the most potent hydroxyl radical scavengers ( $83 \%$ and $81 \%$, respectively), very similar to HBNs 5 and 6 [46], respectively, and in the same range as Trolox (83\%). Finally, among HTNs and compared to PBN, HBNs 5 and 6, HTN3 and HTN2 showed the most potent balanced antioxidant capacity.

Table 5. Antioxidant activity of HTNs 1-3, PBN, HBNs 5, 6, Trolox, and NDGA.

\begin{tabular}{|c|c|c|c|c|c|}
\hline Nitrones/Standards & $C \log P *$ & ILPO (\%) & $\begin{array}{c}\text { LOX Inhibition } \\
\left(\% \text { or } \mathrm{IC}_{50}[\mu \mathrm{M}]\right)( \pm \mathrm{SEM})\end{array}$ & $\begin{array}{c}\text { Scavenger } \\
\text { Activity for }{ }^{\circ} \mathrm{OH}(\%)\end{array}$ & $\begin{array}{l}\text { ABTS }^{+.} \\
(\%)\end{array}$ \\
\hline HTN1 & -2.94 & 46 & $100 \pm 1.1 \mu \mathrm{M}$ & 59 & No \\
\hline HTN2 & 0.77 & 55 & $26 \pm 0.2 \%$ & 81 & No \\
\hline HTN3 & 2.73 & 92 & $70 \pm 2.6 \mu \mathrm{M}$ & 83 & 10 \\
\hline PBN & 3.02 & 11 & $23 \pm 0.1 \%$ & No & 5 \\
\hline HBN5 [46] & 4.51 & 55 & $6 \pm 0.1 \%$ & 67 & No \\
\hline HBN6 [46] & 4.96 & 37 & $29 \pm 0.3 \%$ & 81 & No \\
\hline NDGA & & & $0.45 \mu \mathrm{M}$ & & \\
\hline Trolox & & 88 & & 83 & 91 \\
\hline
\end{tabular}

Nitrones were tested at $100 \mu \mathrm{M}$. Values are means of three or four different determinations. No-no activity under the experimental conditions. Means within each column differ significantly $(p<0.05)$. nd-not determined. * Biobyte BioByte Corporation, C-QSAR database, 201 W Fourth Str., Suite 204, Claremont CA 91711-4707, USA.

\section{Materials and Methods}

\subsection{Chemistry}

\subsubsection{General Methods}

Compound purification was performed by column chromatography with Merck Silica Gel (40-63 $\mu \mathrm{m})$ or by flash chromatography and the adequate eluent for each case. Reaction course was monitored by thin layer chromatography (t.l.c.), revealing with UV light $(\lambda=254 \mathrm{~nm})$ and ethanolic solution of vanillin or ninhydrin. Melting points were determined using a Reichert Thermo Galen Kofler block and were uncorrected. Samples were dissolved in $\mathrm{CDCl}_{3}$ or DMSO- $d_{6}$ using TMS as internal standard for ${ }^{1} \mathrm{H}$ NMR spectra. In ${ }^{13} \mathrm{C}$ NMR spectra, $\mathrm{CDCl}_{3}$ central signal (77.0 ppm) and DMSO-d (39.5 ppm) were used as references. ${ }^{1} \mathrm{H}-\mathrm{NMR}$ and ${ }^{13} \mathrm{C}-\mathrm{NMR}$ spectra were obtained in Bruker Avance $300(300 \mathrm{MHz})$ and Bruker Avance $400 \mathrm{III} \mathrm{HD}(400 \mathrm{~Hz})$ spectrometers. Chemical shifts $(\delta)$ are given in ppm. Coupling constants $(J)$ are given in $\mathrm{Hz}$. Signal multiplicity is abbreviated as singlet $(\mathrm{s})$, doublet $(\mathrm{d})$, triplet $(\mathrm{t})$, quartet $(\mathrm{c})$, doublet of doublets $(\mathrm{dd})$, triplet of doublets (td), or multiplet (m). IR spectra were recorded on a Perkin-Elmer Spectrum One B spectrometer. Units are $\mathrm{cm}^{-1}$. Low resolution mass spectra were recorded on an Agilent HP 1100 LC/MS Spectrometer, whereas High Resolution mass spectrometry (Exact Mass) was performed in an AGILENT 6520 Accurate-Mass QTOF LC/MS Spectrometer. Elemental analysis was performed in an Elementary Chemical Analyzer LECO CHNS-932.

\subsubsection{General Method for the Synthesis of HTNs}

To a suspension of benzene-1,3,5-tricarbaldehyde $(1 \mathrm{mmol})$ in dry THF $(20 \mathrm{~mL})$, anhydrous $\mathrm{NaHCO}_{3}$ (3 equiv), $\mathrm{Na}_{2} \mathrm{SO}_{4}$ (4 equiv) and the corresponding $\mathrm{N}$-alkylhydroxylamine hydrochloride 
( 3 equiv) were added. The mixture was irradiated at $90^{\circ} \mathrm{C}$, and $15 \mathrm{bar}$, for the time indicated in each case. Then, the mixture was cooled, the solvent removed, and the crude purified by column chromatography.

\subsection{3. (1. Z,1'Z,1"Z)-1,1',1"-(Benzene-1,3,5-triyl)tris(N-methylmethanimine oxide) (HTN1)}

Following the general method, the reaction of benzene-1,3,5-tricarbaldehyde (113,4 $\mathrm{mg}, 0,7 \mathrm{mmol})$ with $\mathrm{NaHCO}_{3}(229,3 \mathrm{mg}, 2,73 \mathrm{mmol}), \mathrm{Na}_{2} \mathrm{SO}_{4}(397,6 \mathrm{mg}, 2,73 \mathrm{mmol})$, and $\mathrm{N}$-methylhydroxylamine hydrochloride $(228,1 \mathrm{mg}, 2,73 \mathrm{mmol})$, in THF ( $20 \mathrm{~mL})$, for $6 \mathrm{~h}$, after work-up and purification by column chromatography eluting with MeOH: $\mathrm{CH}_{2} \mathrm{Cl}_{2} 8 \%$, gave HTN1 (123,8 mg, 71\%): $\mathrm{mp}>220{ }^{\circ} \mathrm{C}$; IR $(\mathrm{KBr})$ $v$ 3422, 1598, 1412, 1187, $1158 \mathrm{~cm}^{-1} ;{ }^{1} \mathrm{H}$ NMR $\left(400 \mathrm{MHz}\right.$, DMSO-d $\left._{6}\right) \delta 9.11$ (s, 3 H, H-7, H-9, H-11), 7.96 (s, $3 \mathrm{H}, \mathrm{H}-2, \mathrm{H}-4, \mathrm{H}-6), 3.81$ (s, 9 H, CH CH$_{3} ;{ }^{13} \mathrm{C}$ NMR (101 MHz, DMSO-d 6 ) $\delta 133.9$ (3 C, C-2, C-4, C-6), 131.7 (3 C, C-1, C-3, C-5), 128.2 (3 C, C-7, C-9, C-11), 54.6 (3 C, CH CH $_{3}$, MS (ES) m/z (\%): 249 [M+1] $]^{+}, 271$ $[\mathrm{M}+\mathrm{Na}]^{+}$. Anal. Calcd for $\mathrm{C}_{12} \mathrm{H}_{15} \mathrm{~N}_{3} \mathrm{O}_{3} .2 / 3 \mathrm{H}_{2} \mathrm{O}: \mathrm{C}, 55.16 ; \mathrm{H}, 6.30 ; \mathrm{N}, 16.08$. Found: $\mathrm{C}, 55.12 ; \mathrm{H}, 6.12$; $\mathrm{N}, 15.89$.

\subsection{4. (1. Z,1'Z,1'Z)-1,1',1'-(Benzene-1,3,5-triyl)tris(N-tert-butylmethanimine oxide) (HTN2)}

Following the general method, the reaction of benzene-1,3,5-tricarbaldehyde ( $81 \mathrm{mg}, 0.5 \mathrm{mmol})$ with $\mathrm{NaHCO}_{3}(163.8 \mathrm{mg}, 1.95 \mathrm{mmol}), \mathrm{Na}_{2} \mathrm{SO}_{4}(284 \mathrm{mg}, 2 \mathrm{mmol})$, and $\mathrm{N}$-t-butylhydroxylamine hydrochloride ( $244.9 \mathrm{mg}, 1.95 \mathrm{mmol})$, in THF $(20 \mathrm{~mL})$, for $15.5 \mathrm{~h}$, after work-up and purification by column chromatography eluting with AcOEt, gave HTN2 (123.8 mg, 59\%): $\mathrm{mp}>220^{\circ} \mathrm{C}$; IR (KBr) v 3434, 2975, 1562, 1361, $1172 \mathrm{~cm}^{-1}{ }^{1}{ }^{1} \mathrm{H}$ NMR (400 MHz, DMSO-d 6 ) $\delta 9.33$ (s, 3 H, H-7, H-9, H-11), 7.86 (s, $3 \mathrm{H}, \mathrm{H}-2, \mathrm{H}-4, \mathrm{H}-6), 3.33$ (s, $\left.27 \mathrm{H}, \mathrm{C}\left(\mathrm{CH}_{3}\right)_{3}\right]$; ${ }^{13} \mathrm{C}$ NMR $\left(101 \mathrm{MHz}, \mathrm{DMSO}-d_{6}\right) \delta 131.8$ (3 C, C-1, C-3, C-5), 129.5 (3 C, C-7, C-9, C-11), 128.8 (3 C, C-2, C-4, C-6), 71.1 (3 C, C-8, C-10, C-12), 28.3 [9 C, C( $\left.\left.\mathrm{CH}_{3}\right)_{3}\right]$; MS (ES) $m / z(\%): 376[\mathrm{M}+1]^{+}, 398[\mathrm{M}+\mathrm{Na}]^{+}$. Anal. Calcd for $\mathrm{C}_{21} \mathrm{H}_{33} \mathrm{~N}_{3} \mathrm{O}_{3}: \mathrm{C}, 67.17 ; \mathrm{H}, 8.86 ; \mathrm{N}, 11.19$. Found: $\mathrm{C}, 66.94 ; \mathrm{H}, 8.87 ; \mathrm{N}, 11.07$.

\subsection{5. (1. Z,1'Z,1"Z)-1,1',1'-(Benzene-1,3,5-triyl)tris(N-benzylmethanimine oxide) (HTN3)}

Following the general method, the reaction of benzene-1,3,5-tricarbaldehyde ( $81 \mathrm{mg}, 0.5 \mathrm{mmol})$ with $\mathrm{NaHCO}_{3}(163.8 \mathrm{mg}, 1.95 \mathrm{mmol}), \mathrm{Na}_{2} \mathrm{SO}_{4}(284 \mathrm{mg}, 2 \mathrm{mmol})$, and $\mathrm{N}$-benzylhydroxylamine hydrochloride ( $310.1 \mathrm{mg}, 1.95 \mathrm{mmol})$, in THF $(20 \mathrm{~mL})$, for $6 \mathrm{~h}$, after work-up and purification by column chromatography eluting with AcOEt, gave HTN3 (203.2 mg, 85\%): mp 165-7 ${ }^{\circ} \mathrm{C}$; IR (KBr) v 3429, 1580, 1580, 1496, 1457, $1176 \mathrm{~cm}^{-1}$; ${ }^{1} \mathrm{H}$ NMR (400 MHz, DMSO-d6) $\delta 9.13$ (s, $3 \mathrm{H}, \mathrm{H}-7, \mathrm{H}-10, \mathrm{H}-13$ ), 8.18 (s, 3 H, H-2, H-4, H-6), 7.54-7.29 (m, 15 H, C $6 \mathrm{H}_{5}$ ), 5.09 (s, $\left.6 \mathrm{H}, \mathrm{H}-7, \mathrm{H}-11, \mathrm{H}-14\right)$ ) ${ }^{13} \mathrm{C}$ NMR (101 MHz, DMSO-d 6 ) $\delta 135.1$ (3 C, $\left.\mathrm{C}_{6} \mathrm{H}_{5}\right), 133.2$ (3 C, C-2, C-4, C-6), 131.6 (3 C, C-1, C-3, C-5), 129.5 (6 C, $\left.\mathrm{C}_{6} \mathrm{H}_{5}\right), 128.9$ (6 C, $\left.\mathrm{C}_{6} \mathrm{H}_{5}\right), 128.8\left(3 \mathrm{C}_{2} \mathrm{C}_{6} \mathrm{H}_{5}\right), 128.6$ (3 C, C-7, C-10, C-13), 70.6 (3 C, C-7, C-11, C-14); MS (ES) $\mathrm{m} / \mathrm{z}(\%): 478[\mathrm{M}+1]^{+}, 500[\mathrm{M}+\mathrm{Na}]^{+}$. Anal. Calcd for $\mathrm{C}_{30} \mathrm{H}_{27} \mathrm{~N}_{3} \mathrm{O}_{3} \cdot 1 / 5 \mathrm{H}_{2} \mathrm{O}: \mathrm{C}, 74.89 ; \mathrm{H}, 5.74 ; \mathrm{N}$, 8.73. Found: $\mathrm{C}, 74.87 ; \mathrm{H}, 5.81 ; \mathrm{N}, 8.76$.

\subsection{Neuroprotection Assessment Assays}

\subsubsection{Neuroblastoma Cell Cultures}

The human neuroblastomas cell line SH-SY5Y were cultured in Dulbecco's: Ham's F12, 1:1 [vol/vol] containing $3.15 \mathrm{mg} / \mathrm{mL}$ glucose, $2.5 \mathrm{mM}$ Glutamax and $0.5 \mathrm{mM}$ sodium pyruvate DMEM/F-12, GlutaMAX ${ }^{\mathrm{TM}}$; GIBCO, Life Technologies, Madrid (Spain), 1\% Antibiotique-Antimitotic (Gibco; Life Technologies, Madrid, Spain) (containing $100 \mathrm{ui} / \mathrm{mL}$ penicillin, $100 \mathrm{mg} / \mathrm{mL}$ of streptomycin and $0.25 \mathrm{mg}$ of amphotericine B), $1 \%$ gentamicina $15 \mathrm{mg} / \mathrm{mL}$ (Sigma-Aldrich, Madrid, España) and 10\% Foetal Calf Serum (FCS) (Gibco; Life Technologies, Madrid, Spain) as described [46,49]. Cultures were seeded into flasks containing supplemented medium and maintained at $37^{\circ} \mathrm{C}$ in a humidified atmosphere of $5 \%$ $\mathrm{CO}_{2}$ and $95 \%$ air. Culture media were changed every $2 \mathrm{~d}$. Cells were subcultured after partial digestion with $0.25 \%$ trypsin-EDTA. For assays, SHSY5Y cells were subcultured in 96- or 48-well plates at a seeding density of $0.50-1$ or $2-2.5 \times 10^{5}$ or cells per well, respectively. When the SHSY5Y cells reached 
$80 \%$ confluence, the medium was replaced with fresh medium containing $0.01-1000 \mu \mathrm{M}$ compound concentrations or PBS in the controls, as indicated in each assay.

\subsubsection{Neuroblastoma Cell Cultures Exposure to Oxygen Glucose Deprivation}

Neuroblastoma cell cultures were exposed to OGD so as to induce cellular damage (experimental ischemia) as described [46]. Cultured cells were washed and placed in glucose-free Dulbecco's medium (bubbled with $95 \% \mathrm{~N}_{2} / 5 \% \mathrm{CO}_{2}$ for $30 \mathrm{~min}$ ) and maintained in an anaerobic chamber containing a gas mixture of $95 \% \mathrm{~N} 2 / 5 \% \mathrm{CO}_{2}$ and humidified at $37{ }^{\circ} \mathrm{C}$ at a constant pressure of 0.15 bar. Cells were exposed to OGD for a period of $4 \mathrm{~h}$ (OGD $4 \mathrm{~h}$ ), as indicated. At the end of the OGD period, culture medium was replaced with oxygenated serum-free medium, and cells were placed and maintained in the normoxic incubator for $24 \mathrm{~h}$ to recovery (R24h). In the neuroprotection experiments, HTNs 1-3 and PBN $(0.01 \mu \mathrm{M}-1 \mathrm{mM})$ were added at the beginning of recovery period (see below). Control cultures in Dulbecco's medium containing glucose were kept in the normoxic incubator for the same period of time as the OGD $(\mathrm{C} 4 \mathrm{~h})$, and then culture medium was replaced with fresh medium and cells were returned to the normoxic incubator until the end of recovery period (C24h). Control experiments included the same amounts of vehicle (final concentration $<0.01 \%$ dimethyl sulfoxide). The experimental procedures were blindly performed, assigning a random order to each assayed nitrone. Nitrones were analyzed independently 3-5 times with different batches of cultures, and each experiment was run in triplicate.

\subsubsection{Assessment of Cell Viability}

Measurements of cell viability in human SHSY5Y neuroblastoma cells were carried out into 96well culture plates as described [46,50]. Briefly, control and treated SH-SY5Y neuroblastoma cells (about $0.75-1 \times 105$ cells/well) were incubated with the XTT solution (Cell Proliferation Kit II (XTT), Sigma, Aldrich, Madrid) at $0.3 \mathrm{mg} / \mathrm{mL}$ final concentration for $2 \mathrm{~h}$ in a humidified incubator at $37^{\circ} \mathrm{C}$ with $5 \% \mathrm{CO}_{2}$ and $95 \%$ air $(v / v)$ and the soluble orange formazan dye formed was spectrophotometrically quantified, using a Biotek Power-Wave XS spectrophotometer microplate-reader at $450 \mathrm{~nm}$ (reference $650 \mathrm{~nm}$ ). All XTT assays were performed in triplicate in cells of at least three different cell batches. Control cells treated with DMEM alone were regarded as $100 \%$ viability. Controls containing different DMSO concentrations (0.001-1\% DMSO) were performed in all assays.

\subsubsection{Measurement of LDH Activity}

For these assays, cultured neuroblastoma cells grown in 96-well culture dishes at a density of $1.5 \times 105$ cells/well were used. LDH activity was measured as the rate of decrease of the absorbance at $340 \mathrm{~nm}$, resulting from the oxidation of NADH to NAD+ as described [46,51]. Data are given as the percentage of LDH release with respect to the total LDH content (LDH in the culture medium and LDH inside the cells).

\subsubsection{Analysis of Caspase-3 Activity}

For these assays, cultured neuroblastoma cells grown in 48-well culture dishes, at a density of $2.5 \times 10^{5}$ cells/well, were used. After OGD treatment, cells were treated with different nitrones or indicated positive controls at 1-500 $\mu \mathrm{M}$ concentrations and subjected to $24 \mathrm{~h} \mathrm{IR}$. Attached cells were lysed at $4{ }^{\circ} \mathrm{C}$ in a lysis medium containing $5 \mathrm{mM}$ Tris/ $\mathrm{HCl}(\mathrm{pH} 8.0), 20 \mathrm{mM}$ ethylenediaminetetraacetic acid, and $0.5 \%$ Triton X-100 and centrifuged at $13,000 \mathrm{~g}$ for $10 \mathrm{~min}$. The activity of caspase- 3 was measured using the fluorogenic substrate peptide DEVD-amc (66081; BD Biosciences PharMingen), as described $[46,51]$. Proteins were measured by the Bradford assay. Results were expressed as arbitrary fluorescence units [(AFU)/ $\mu \mathrm{g}$ protein/h]. 


\subsubsection{Measurement of Reactive Oxygen Species Formation}

SHSY5Y human neuroblastoma cells $\left(2 \times 10^{5}\right.$ cells/well $)$ were exposed to OGD for a period of $4 \mathrm{~h}$ (OGD4h). At the end of the OGD period, the culture medium was replaced with oxygenated Dulbecco's modified Eagle's medium containing glucose and $10 \%$ fetal calf serum. Cells were treated in the absence (controls) or presence of indicated concentrations of nitrones or different known neuroprotective agents and maintained at $37^{\circ} \mathrm{C}$ in a normoxic incubator for $3 \mathrm{~h}$ for recovery. At the end of this period, $20 \mu \mathrm{M}$ DHE (HEt; Molecular Probes) was added and fluorescence was recorded every 15-30 s during a 15 min period, using an excitation filter of $535 \mathrm{~nm}$ and an emission filter of $635 \mathrm{~nm}$ in a spectrofluorimeter (Bio-Tek FL 600) as previously described [46,52]. Linear regression of fluorescence data [expressed as arbitrary fluorescence units (AFU)] was calculated for each condition, and the slopes (a) of the best fitting lines $(\mathrm{y}=\mathrm{ax})$ were considered as an index of $\mathrm{O}_{2}{ }^{\bullet-}$ production [52].

\subsubsection{Statistical Analysis}

Data were expressed as mean \pm SEM of results obtained from at least three independent experiments from different cultures, each of which was performed in triplicate. Statistical comparisons between the different experimental conditions were performed using one-way analysis of variance (ANOVA), followed by Holm-Sidak's post -test when the analysis of variance was significant. A $p$ value $<0.05$ was considered statistically significant. Fit curves for $\mathrm{EC}_{50}$ determinations were performed according to the program of SigmaPlot v.11 (Systat Software Inc., Germany), 2012).

\subsection{Antioxidant Activity Tests of HTNs 1-3, PBN, Trolox, and NDGA in Vitro}

\subsubsection{Estimation of Lipophilicity as Clog $\mathrm{P}$}

Bioloom of Biobyte Corp was used for the theoretical calculation of lipophilicity as $C \log p$ values (BioByte Home Page. Available online: http://www.biobyte.com).

\subsubsection{General Methods}

Nordihydroguaiaretic acid (NDGA), Trolox, 2,2'-azobis(2-amidinopropane) dihydrochloride (AAPH), Soybean LOX linoleic acid sodium salt were purchased from the Aldrich Chemical Co. Milwaukee, WI, (USA). Phosphate buffer (0.1 M and pH 7.4) was prepared mixing an aqueous $\mathrm{KH}_{2} \mathrm{PO}_{4}$ solution $(50 \mathrm{~mL}, 0.2 \mathrm{M})$, and an aqueous of $\mathrm{NaOH}$ solution $(78 \mathrm{~mL}, 0.1 \mathrm{M})$; the $\mathrm{pH}(7.4)$ was adjusted by adding a solution of $\mathrm{KH}_{2} \mathrm{PO}_{4}$ or $\mathrm{NaOH}$ ). For the in vitro tests a Lambda 20 (Perkin-Elmer-PharmaSpec 1700) UV-Vis double beam spectrophotometer was used.

\subsubsection{Inhibition of Linoleic Acid Peroxidation}

For initiating the free radical, 2,2'-azobis(2-amidinopropane) dihydrochloride (AAPH) was used. The final solution in the UV cuvette consisted of $10 \mu \mathrm{L}$ of the $16 \mathrm{mM}$ linoleate sodium dispersion, $0.93 \mathrm{~mL}$ of $0.05 \mathrm{M}$ phosphate buffer, $\mathrm{pH} 7.4$, thermostated at $37^{\circ} \mathrm{C}$. A total of $50 \mu \mathrm{L}$ of $40 \mathrm{mM} \mathrm{AAPH}$ solution was added as a free radical initiator at $37^{\circ} \mathrm{C}$ under air and $10 \mu \mathrm{L}$ of the tested compounds. The oxidation of linoleic acid sodium salt results a conjugated diene hydroperoxide. The reaction was monitored at $234 \mathrm{~nm}$.

\subsubsection{Soybean Lipoxygenase Inhibition Study}

DMSO solution of the tested compound (stock solutions $10 \mathrm{mM}$ ) was incubated with sodium linoleate $(0.1 \mathrm{mM})$ and $0.2 \mathrm{~mL}$ of soybean lipoxygenase solution $\left(1 / 9 \times 10^{-4} \mathrm{w} / \mathrm{v}\right.$ in saline $)$ at room temperature. The test followed our previous published methods [53]. The conversion of sodium linoleate to 13-hydroperoxylinoleic acid was recorded at $234 \mathrm{~nm}$ and compared with the standard inhibitor NDGA $\left(\mathrm{IC}_{50}=0.45 \mu \mathrm{M} / 935\right.$ at $\left.100 \mu \mathrm{M}\right)$. Several concentrations were used to determine the $\mathrm{IC}_{50}$. 


\subsubsection{ABTS $^{+\bullet}$ —Decolorization Assay for Antioxidant Activity}

The ABTS radical cation $\left(\mathrm{ABTS}^{+\bullet}\right)$ was generated from an ABTS stock solution in water $(7 \mathrm{mM})$ which was mixed with potassium persulfate $(2.45 \mathrm{mM})$ and left in the dark at room temperature for 12-16 $\mathrm{h}$ before use. The results were recorded after $1 \mathrm{~min}$ of the mixing solutions at $734 \mathrm{~nm}$ and compared to the appropriate standard inhibitor Trolox [53].

\subsubsection{Hydroxyl Radical Scavenging Activity}

The hydroxyl radicals were produced by the $\mathrm{Fe}^{3+} /$ ascorbic acid system. EDTA $(0.1 \mathrm{mM}), \mathrm{Fe}^{3+}$ $(167 \mu \mathrm{M})$, DMSO $(33 \mathrm{mM})$ in phosphate buffer $(50 \mathrm{mM}, \mathrm{pH} 7.4)$, the tested compounds $(0.1 \mathrm{mM})$, and ascorbic acid $(10 \mathrm{mM})$ were mixed in test tubes. The solutions were incubated at $37^{\circ} \mathrm{C}$ for 30 min. The reaction was stopped by $\mathrm{CCl}_{3} \mathrm{COOH}(17 \% w / v)$ and the $\%$ scavenging activity of the tested compounds for hydroxyl radicals was given.

\section{Conclusions}

In this work we described the design, synthesis, neuroprotection, and antioxidant capacity of HTNs 1-3 derived from PBN, comparing them with HBN6 (Figure 1), our most recently discovered potent neuroprotective homo-bis-nitrone [46]. The biological evaluation of these HTNs included neuroprotection against $\mathrm{O} / \mathrm{R}$, an ischemia in vitro model under OGD conditions in human neuroblastoma SH-SY5Y cells, and diverse antioxidant tests.

Our design, supported by our previous report [46], was based on the hypothesis that three nitrone motifs installed in the same scaffold should afford higher neuroprotective power than two nitrone groups. In other words, the greater the number of nitrone free radical scavenging groups, the stronger the antioxidant and neuroprotective properties.

The neuroprotection of HTNs 1-3, measured against O/R, showed that HTN2 was the best neuroprotective agent at a lower dose $\left(\mathrm{EC}_{50}=51.63 \pm 4.32 \mu \mathrm{M}\right)$, but HTN3 produced the greater neuroprotection at a higher dose $\left(\mathrm{EC}_{50}=125.57 \pm 6.19 \mu \mathrm{M}\right), \mathrm{HTN} 2$ being similar in $\mathrm{EC}_{50}$ and maximal activity to PBN and less potent than any of HBNs 4-6. The results of neuroprotection in an in vitro oxygen glucose deprivation model showed that HTN2 was the most powerful, $\mathrm{EC}_{50}=87.57,3,87 \mu \mathrm{M}$, at lower dose, but 50-fold higher than its analogous HBN5, and $\approx 1.7$-fold less potent than PBN, but again HTN3 produced the greater neuroprotection at a higher dose $\left(\mathrm{EC}_{50}=124.06 \pm 7.40 \mu \mathrm{M}\right)$. HTN3 has a very good antinecrotic $\left(\mathrm{IC}_{50}=3.47 \pm 0.57 \mu \mathrm{M}\right)$, antiapoptotic, and antioxidant $\left(\mathrm{EC}_{50}=6.77\right.$ $\pm 1.35 \mu \mathrm{M}$ ), profile, very similar to that of its analogous HBN6. Finally, HTN3 was able to inhibit $92 \% \mathrm{LP}, \mathrm{LOX}(70 \mu \mathrm{M})$, and $\mathrm{ABTS}^{+}(10 \%)$, showing high hydroxyl radical scavenger capacity $(83 \%)$ and exhibiting thus the potent balanced antioxidant capacity among the nitrones investigated here. However, the results of the present work show that in general, the HTNs 1-3 do not have better properties than HBN6, but clearly exceed PBN. From the point of view of our drug design, it is clear that the introduction of a third, additional nitrone group seems not to provide an additional, accumulative benefit to the neuroprotective, and antioxidant activity previously observed for HBN5 and HBN6 [46], bearing two nitrone groups. In other words, "more is better, but much more is worse" (Figure 8).

Furthermore, these results confirmed what we have reported in a previous communication [54]. Thus, based on the ability of the "N-propargylamine" motif to impart MAO inhibition, we wondered whether the progressive incorporation of 1,2 , or 3 " $N$-propargylamine" motives in a simple core provided by the 1,3,5-triazine could afford progressive, accumulative, and higher MAO inhibition power. The observed results clearly showed again that much more is worse, that the incorporation of more anti-MAO pharmacophores is not a guarantee for better inhibition. On the contrary, less inhibition or no inhibition was detected, and only ligand 4,6-dichloro- $N$-(prop-2-yn-1-yl)-1,3,5-triazin-2-amine bearing a single $\mathrm{N}$-propargylamine $\mathrm{MAO}$ pharmacophore motif, showed modest, but totally selective MAO-B inhibition [54]. 


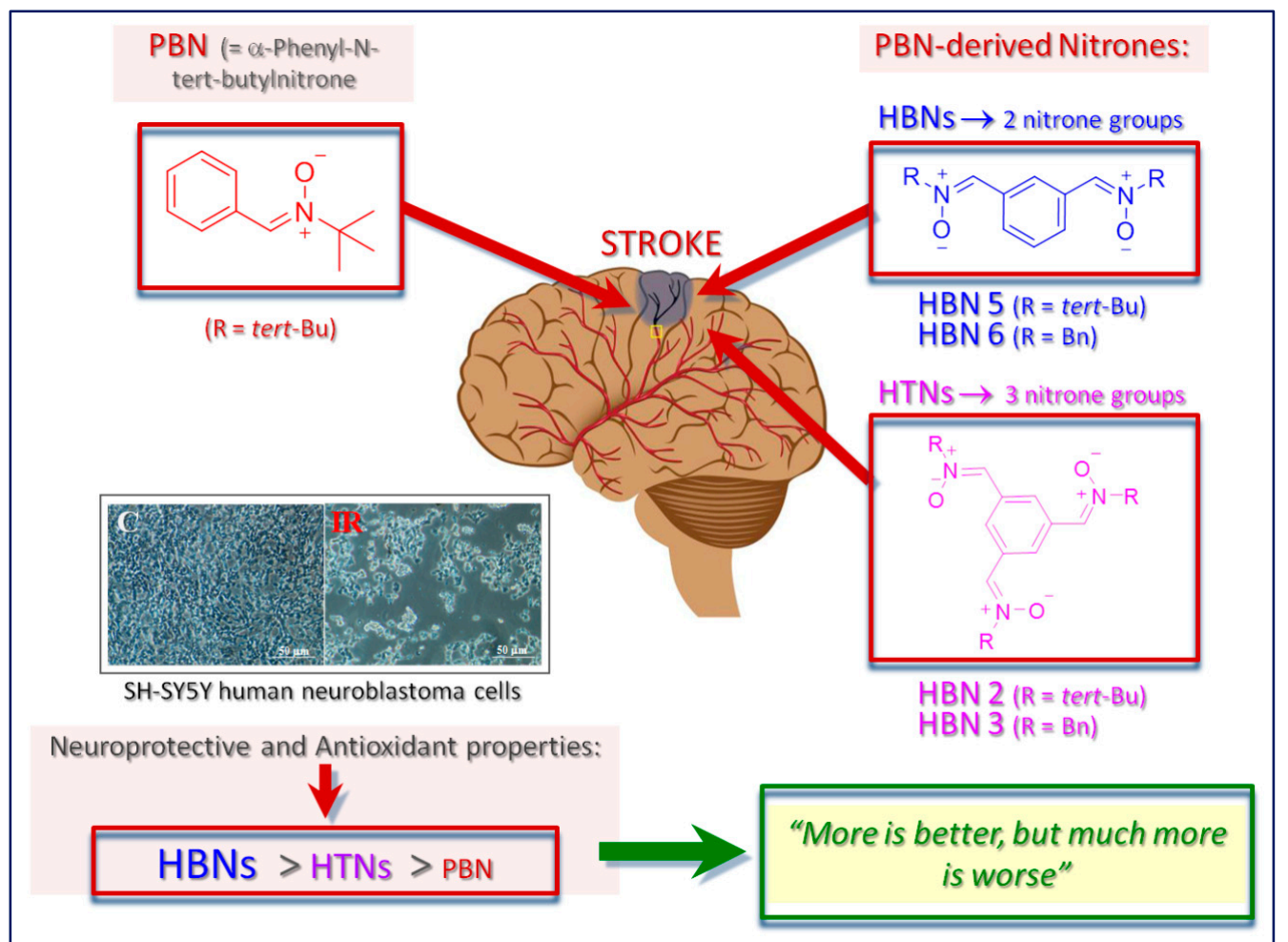

Figure 8. Graphic diagram showing the most important conclusions of this work. HTNs 2 and 3 have a good antioxidant and neuroprotective activity against necrotic and apoptotic cell death, very similar to those of their homologous HBN5 and HBN6. However, they have a worse capacity than their counterparts to reverse the cellular metabolic alterations induced by oligomycin A/rotenone and by in vitro ischemia/reperfusion in human neuroblastoma SH-SY5Y cells. Therefore, although HTNs 2 and 3 overcome the antioxidant and neuroprotective properties of PBN, the addition of a third nitrone group does not improve, but rather worsens, the neuroprotective capacity observed in HBN5 and HBN6. In other words, "more is better, but much more is worse".

The present result is not necessarily negative, as it was an obvious necessary development in our current program to identify new and more efficient nitrones for therapeutic purposes, and this is possibly a general trend that should be taken into account in drug discovery projects [54]. Consequently, our present endeavors in this arena are now directed to the rational and wise structural modification of HBN5 and HBN6 (Figure 1) to improve its neuroprotective and antioxidant properties [46].

Supplementary Materials: Supplementary Materials (NMR spectra of HTNs 1-3) can be found at http://www. mdpi.com/1422-0067/21/21/7949/s1.

Author Contributions: J.M.-C. designed the molecules and supervised their synthesis; D.D.-I. carried out the synthesis of HTNs 1-3; B.C. and M.T. performed the neuroprotection studies; M.C. carried out the analysis of the nitrones; D.H.-L. performed the antioxidant tests; M.J.O.-G. designed, supervised, analyzed, and coordinated the neuroprotection studies; M.J.O.-G. and J.M.-C. wrote the manuscript; M.J.O.-G., J.M.-C., I.I. and F.L.-M. corrected the manuscript. All authors have read and agreed to the published version of the manuscript.

Funding: This work was supported by grants from the Spanish Ministry of Economy and Competitiveness (SAF2015-65586-R) to J.M.-C. and Camilo José Cela University (UCJC-2018-04) to M.J.O.-G.

Acknowledgments: Hadjipavlou-Litina thanks Biobyte for the free use of C-QSAR platform. D.D.-I. thanks the Spanish Ministry of Science, Innovation and Universities for pre-doctoral FPU grant. B.C. thanks the UCJC for a pre-doctoral FPI grant.

Conflicts of Interest: The authors declare no competing financial interest. The funders had no role in the design of the study; in the collection, analyses, or interpretation of data; in the writing of the manuscript, or in the decision to publish the results. 


\section{Abbreviations}

$\begin{array}{ll}\text { AAPH } & \text { 2,2'-Azobis(2-amidinopropane) dihydrochloride } \\ \text { NAC } & \text { N-Acetyl-L-cysteine } \\ \text { BBB } & \text { Blood-brain barrier } \\ \text { HBNs } & \text { Homo-bis-nitrones } \\ \text { HTNs } & \text { Homo-tris-nitrones } \\ \text { IR } & \text { Ischemic reperfusion } \\ \text { LDH } & \text { Lactate dehydrogenase } \\ \text { LOX } & \text { Lipoxygenase } \\ \text { LP } & \text { Lipid peroxidation } \\ \text { MTT } & \text { 3-(4,5-Dimethylthiazol-2-yl)-2,5-diphenyltetrazolium bromide } \\ \text { NDGA } & \text { Nordihydroguaiaretic acid } \\ \text { O/R } & \text { Oligomycin A/Rotenone } \\ \text { OGD } & \text { Oxygen Glucose Deprivation } \\ \text { PBN } & \alpha \text {-Phenyl- } N \text {-tert-butylnitrone } \\ \text { ROS } & \text { Reactive oxygen species }\end{array}$

\section{References}

1. Tanaka, M.; Bohár, Z.; Vécsei, L. Are kynurenines accomplices or principal villains in dementia? Maintenance of kynurenine metabolism. Molecules 2020, 25, 564. [CrossRef]

2. Tanaka, M.; Vécsei, L. Monitoring the redox status in multiple sclerosis. Biomedicines 2020, 8, 406. [CrossRef]

3. Catanesi, M.; d'Angelo, M.; Tupone, M.G.; Benedetti, E.; Giordano, A.; Castelli, V.; Cimini, A. 438 MicroRNAs dysregulation and mitochondrial dysfunction in neurodegenerative diseases. Int. J. Mol. Sci. 2020, 21, 5986. [CrossRef]

4. Azzi, A. Antioxidants: Wonder drugs or quackery? BioFactors 2017, 43, 785-788. [CrossRef] [PubMed]

5. Nicole, O.; Docagne, F.; Ali, C.; Margaill, I.; Carmeliet, P.; MacKenzie, E.T.; Vivien, D.; Buisson, A. The proteolytic activity of tissue-plasminogen activator enhances NMDA receptor-mediated signaling. Nat. Med. 2001, 7, 59-64. [CrossRef] [PubMed]

6. Chan, P.H. Cellular Antioxidant Defense Mechanisms; Chow, C.K., Ed.; CRC Press: Boca Ratón, FL, USA, 1988; Volume 3, pp. 89-109.

7. Rosselin, M.; Poeggeler, B.; Durand, G. Nitrone derivatives as therapeutics: From chemical modification to specific-targeting. Curr. Top. Med. Chem. 2017, 17, 2006-2022. [CrossRef] [PubMed]

8. Oliveira, C.; Benfeito, S.; Fernandes, C.; Cagide, F.; Silva, T.; Borges, F. NO and HNO donors, nitrones, and nitroxides: Past, present, and future. Med. Res. Rev. 2018, 38, 1159-1187. [CrossRef] [PubMed]

9. Floyd, R.A.; Kopke, R.D.; Choi, C.-H.; Foster, S.B.; Doblas, S.; Towner, R.A. Nitrones as therapeutics. Free Radic. Biol. Med. 2008, 45, 1361-1374. [CrossRef] [PubMed]

10. Croitoru, M.D.; Ibolya, F.; Pop, M.C.; Dergez, T.; Mitroi, B.; Dogaru, M.T.; Tőkes, B. Nitrones are able to release nitric oxide in aqueous environment under hydroxyl free radical attack. Nitric Oxide 2011, 25, 309-315. [CrossRef]

11. Durand, G.; Choteau, F.; Pucci, B.; Villamena, F.A. Reactivity of superoxide radical anion and hydroperoxyl radical with alpha-phenyl-N-tert-butylnitrone (PBN) derivatives. J. Phys. Chem. A 2008, 112, 12498-12509. [CrossRef]

12. Cao, X.; Phillis, J.W. Phenyl-tert-butyl-nitrone reduces cortical infarct and edema in rats subjected to focal ischemia. Brain Res. 1994, 644, 267-272. [CrossRef]

13. Escobar-Peso, A.; Chioua, M.; Frezza, V.; Martínez-Alonso, E.; Marco-Contelles, J.A.; Alcázar, A. Nitrones, Old fellows for new therapies in ischemic stroke. In Neuroprotective Therapy for Stroke and Ischemic Disease; Lapchak, P.A., Zhang, J.H., Eds.; Springer: Cham, Switzerland, 2017; Chapter 9; pp. 251-283.

14. Maples, K.R.; Green, A.R.; Floyd, R.A. Nitrone-related therapeutics: Potential of NXY-059 for the treatment of acute ischaemic stroke. CNS Drugs 2004, 18, 1071-1084. [CrossRef] [PubMed]

15. Liu, Z.-Q. Bridging free radical chemistry with drug discovery: A promising way for finding novel drugs efficiently. Eur. J. Med. Chem. 2020, 189, 112020. [CrossRef] [PubMed] 
16. Floyd, R.A.; Neto, H.C.C.F.; Zimmerman, G.A.; Hensley, K.; Towner, R.A. Nitrone-based therapeutics for neurodegenerative diseases: Their use alone or in combination with lanthionines. Free Rad. Biol. Med. 2013, 62, 145-156. [CrossRef]

17. Floyd, R.A.; Towner, R.A.; He, T.; Hensley, K.; Maples, K.R. Translational research involving oxidative stress and diseases of aging. Free Radic. Biol. Med. 2011, 51, 931-941. [CrossRef]

18. Mandal, M.N.; Moiseyev, G.P.; Elliott, M.H.; Kasus-Jacobi, A.; Li, X.; Chen, H.; Zheng, L.; Nikolaeva, O.; Floyd, R.A.; Ma, J.-X.; et al. Alpha-phenyl-N-tert-butylnitrone (PBN) prevents light-induced degeneration of the retina by inhibiting RPE65 protein isomerohydrolase activity. J. Biol. Chem. 2011, 286, 32491-32501. [CrossRef]

19. Ewert, D.; Hu, N.; Du, X.; Li, W.; West, M.B.; Choi, C.-H.; Floyd, R.; Kopke, R.D. HPN-07, a free radical spin trapping agent, protects against functional, cellular and electrophysiological changes in the cochlea induced by acute acoustic trauma. PLOS ONE 2017, 12, e0183089. [CrossRef]

20. Novelli, G.P.; Angiolini, P.; Tani, R.; Consales, G.; Bordi, L. Phenyl-t-butyl-nitrone is active against traumatic shock in rats. Free Radic. Res. Commun. 1986, 1, 321-327. [CrossRef]

21. Dias, A.G.; Santos, C.E.V.; Cyrino, F.Z.G.A.; Bouskela, E.; Costa, P.R.R. N-tert-Butyl and N-methyl nitrones derived from aromatic aldehydes inhibit macromolecular permeability increase induced by ischemia/reperfusion in hamsters. Bioorg. Med. Chem. 2009, 17, 3995-3998. [CrossRef]

22. Sun, Y.; Jiang, J.; Zhang, Z.; Yu, P.; Wang, L.; Xu, C.; Liu, W.; Wang, Y. Antioxidative and Thrombolytic TMP Nitrone for Treatment of Ischemic Stroke. Bioorg. Med. Chem. 2008, 16, 8868-8874. [CrossRef]

23. Sun, Y.; Yu, P.; Zhang, G.; Wang, L.; Zhong, H.; Zhai, Z.; Wang, L.; Wang, Y. Therapeutic effects of tetramethylpyrazine nitrone in rat ischemic stroke models. J. Neurosci. Res. 2012, 90, 1662-1669. [CrossRef] [PubMed]

24. Zhang, Z.; Zhang, G.; Sun, Y.; Szeto, S.S.W.; Law, H.C.H.; Quan, Q.; Li, G.; Yu, P.; Sho, E.; Siu, M.K.W.; et al. Tetramethylpyrazine nitrone, a multifunctional neuroprotective agent for ischemic stroke therapy. Sci. Rep. 2016, 6, 37148. [CrossRef]

25. Sun, Y.; Zhang, G.; Zhang, Z.; Yu, P.; Zhong, H.; Du, J.; Wang, Y. Novel multi-functional nitrones for treatment of ischemic stroke. Bioorg. Med. Chem. 2012, 20, 3939-3945. [CrossRef] [PubMed]

26. Socrier, L.; Rosselin, M.; Choteau, F.; Durand, G.; Morandat, S. Cholesterol-nitrone conjugates as protective agents against lipid oxidation: A model membrane study. BBA Biomembranes 2017, 1859, 2495-2504. [CrossRef] [PubMed]

27. Choteau, F.; Durand, G.; Ranchon-Cole, I.; Cercy, C.; Pucci, B. Cholesterol-based-phenyl-N-tert-butyl nitrone derivatives as antioxidants against light-induced retinal degeneration. Bioorg. Med. Chem. Lett. 2010, 20, 7405-7409. [CrossRef] [PubMed]

28. Rosselin, M.; Tuccio, B.; Perio, P.; Villamena, F.A.; Fabre, P.-L.; Durand, G. Electrochemical and spin-trapping properties of para-substituted $\alpha$-phenyl-N-tert-butyl nitrones. Electrochim. Acta 2016, 193, 231-239. [CrossRef]

29. Zeghdaoui, A.; Tuccio, B.; Finet, J.-P.; Cerri, V.; Tordo, P. $\beta$-Phosphorylated $\alpha$-phenyl-N-tert-butylnitrone (PBN) analogues: A new series of spin traps for oxyl radicals. J. Chem. Soc. Perkin Trans. 1995, 2, 2087-2089. [CrossRef]

30. Roubaud, V.; Lauricella, R.; Bouteiller, J.-C.; Tuccio, B. N-2-(2-Ethoxycarbonyl-propyl) $\alpha$-phenylnitrone: An efficacious lipophilic spin trap for superoxide detection. Arch. Biochem. Biophys. 2002, 397, 51-56. [CrossRef]

31. Rosselin, M.; Choteau, F.; Zéamari, K.; Nash, K.M.; Das, A.; Lauricella, R.; Lojou, E.; Tuccio, B.; Villamena, F.A.; Durand, G. Reactivities of substituted $\alpha$-phenyl-N-tert -butyl nitrones. J. Org. Chem. 2014, 79, 6615-6626. [CrossRef]

32. Deletraz, A.; Zéamari, K.; Hua, K.; Combes, M.; Villamena, F.A.; Tuccio, B.; Callizot, N.; Durand, G. Substituted $\alpha$-phenyl and $\alpha$-naphthlyl-N-tert-butyl nitrones: Synthesis, spin-trapping, and neuroprotection evaluation. J. Org. Chem. 2020, 85, 6073-6085. [CrossRef]

33. Balogh, G.T.; Vukics, K.; Könczöl, A.; Kis-Varga, A.; Gere, A.; Fischer, J. Nitrone derivatives of trolox as neuroprotective agents. Bioorg. Med. Chem. Lett. 2005, 15, 3012-3015. [CrossRef] [PubMed]

34. Chioua, M.; Sucunza, D.; Soriano, E.; Hadjipavlou-Litina, D.; Alcázar, A.; Ayuso, I.; Oset-Gasque, M.J.; González, M.P.; Monjas, L.; Rodríguez-Franco, M.I.; et al. Aryl-N-alkyl nitrones, as potential agents for stroke treatment: Synthesis, theoretical calculations, antioxidant, anti-inflammatory, neuroprotective and brain-blood barrier permeability properties. J. Med. Chem. 2012, 55, 153-168. [CrossRef] [PubMed] 
35. Ayuso, M.I.; Chioua, M.; Martínez-Alonso, E.; Soriano, E.; Montaner, J.; Masjuán, J.; Hadjipavlou-Litina, D.; Marco-Contelles, J.; Alcázar, A. Cholesteronitrones for stroke. J. Med. Chem. 2015, 58, 6704-6709. [CrossRef] [PubMed]

36. Ayuso, M.I.; Martínez-Alonso, E.; Chioua, M.; Escobar-Peso, A.; Gonzalo-Gobernado, R.; Montaner, J.; Marco-Contelles, J.; Alcázar, A. Quinolinylnitrone RP19 induces neuroprotection after transient brain ischemia. ACS Chem. Neurosci. 2017, 8, 2202-2213. [CrossRef]

37. Chioua, M.; Salgado-Ramos, M.; Diez-Iriepa, D.; Escobar-Peso, A.; Isabel Iriepa, I.; Hadjipavlou-Litina, D.; Martínez-Alonso, E.; Alcázar, A.; Marco-Contelles, J. Novel quinolylnitrones combining neuroprotective and antioxidant properties. ACS Chem. Neurosci. 2019, 10, 2703-2706. [CrossRef]

38. Chioua, M.; Martinez-Alonso, E.; Gonzalo-Gobernado, R.; Ayuso, M.I.; Escobar-Peso, A.; Infantes, L.; Hadjipavlou-Litina, D.; Montoya, J.J.; Montaner, J.; Alcazar, A.; et al. New quinolylnitrones for stroke therapy: Antioxidant and neuroprotective (Z)-N-tert-butyl-1-(2-chloro-6-methoxyquinolin-3-yl)methanimine oxide as a new lead-compound for ischemic stroke treatment. J. Med. Chem. 2019, 62, 2184-2201. [CrossRef] [PubMed]

39. Becker, D.A.; Ley, J.J.; Echegoyen, L.; Alvarado, R. Stilbazulenyl nitrone (STAZN): A nitronyl-substituted hydrocarbon with the potency of classical phenolic chain-breaking antioxidants. J. Am. Chem. Soc. 2002, 124, 4678-4684. [CrossRef]

40. Ginsberg, M.D.; Becker, D.A.; Busto, R.; Belayev, A.; Zhang, Y.; Khoutorova, L.; Ley, J.J.; Zhao, W.; Belayev, L. Stilbazulenyl nitrone, a novel antioxidant, is highly neuroprotective in focal ischemia. Ann. Neurol. 2003, 54, 330-342. [CrossRef]

41. Lapchak, P.A.; Schubert, D.R.; Maher, P.A. De-risking of stilbazulenyl nitrone (stazn), a lipophilic nitrone to treat stroke using a unique panel of in vitro assays. Trans. Stroke Res. 2011, 2, 209-217. [CrossRef]

42. Althaus, J.S.; Fleck, T.J.; Becker, D.A.; Hall, E.D.; Von Voigtlander, P.F. Azulenyl nitrones: Colorimetric detection of oxyradical end products and neuroprotection in the gerbil transient forebrain ischemia/reperfusion model. Free Radical Biol. Med. 1998, 24, 738-744. [CrossRef]

43. Xu, D.; Duan, H.; Zhang, Z.; Cui, W.; Wang, L.; Sun, Y.; Lang, M.; Hoy, P.M.; Han, Y.; Wang, Y.; et al. The novel tetramethypyrazine bis-nitrone (TN-2) protects against MPTP/MPP+-induced neurotoxicity via inhibition of mitochondrial-dependent apoptosis. J. Neuroimmune Pharmacol. 2014, 9, 245-258. [CrossRef] [PubMed]

44. Xu, D.-P.; Zhang, K.; Zhang, Z.-J.; Sun, Y.-W.; Guo, B.-J.; Wang, Y.-Q.; Hoi, P.-M.; Han, Y.-F.; Lee, S.M.-Y. A Novel Tetramethylpyrazine bis-nitrone (TN-2) protects against 6-hydroxyldopamine-induced neurotoxicity via modulation of the NF- $\mathrm{BB}$ and the PKC $\alpha / \mathrm{PI} 3-\mathrm{K} /$ Akt pathways. Neurochem. Int. 2014, 78, 76-85. [CrossRef] [PubMed]

45. Sun, Y.; Liao, K.; Li, S.; Zhang, Z.; Yu, P.; Wang, Y. Pharmacokinetic analysis of tetramethylpyrazine bis-nitrone TN-2 in rats and its protein binding in vitro. Lett. Drug Des. Discov. 2014, 11, 770-777. [CrossRef]

46. Chamorro, B.; Diez-Iriepa, D.; Merás-Sáiz, B.; Chioua, M.; García-Vieira, D.; Iriepa, I.; Hadjipavlou-Litina, D.; López-Muñoz, F.; Martínez-Murillo, R.; González-Nieto, D.; et al. Synthesis, antioxidant properties and neuroprotection of $\alpha$-phenyl-tert-butylnitrone derived HomoBisNitrones in in vitro and in vivo ischemia models. Sci. Rep. 2020, 10, 14150. [CrossRef] [PubMed]

47. Tien, M.-J.; Wang, Y.; Ho, T.-I.; Chiang, L.Y. Synthesis and magnetic properties of stable nitroxyl tri-radicals. Synth. Metals 1997, 85, 1675-1676. [CrossRef]

48. Carney, J.M.; Floyd, R.A. Spin trapping agents for the treatment of diseases associated with oxidation of lipids and proteins. PCT Int. Appl. 1992, 32, S22-S27, WO9222290.

49. Jiménez-Almarza, A.; Diez-Iriepa, D.; Chioua, M.; Chamorro, B.; Iriepa, I.; Martínez-Murillo, R.; Hadjipavlou-Litina, D.; Oset-Gasque, M.J.; Marco-Contelles, J. Synthesis, neuroprotective and antioxidant capacity of PBN-related indanonitrones. Bioorg. Chem. 2019, 86, 445-451. [CrossRef]

50. García-Font, N.; Hayour, H.; Belfaitah, A.; Pedraz, J.; Moraleda, I.; Iriepa, I.; Bouraiou, A.; Chioua, M.; Marco-Contelles, J.; Oset-Gasque, M.J. Potent anticholinesterasic and neuroprotective pyranotacrines as inhibitors of beta-amyloid aggregation, oxidative stress and tau-phosphorylation for Alzheimer's disease. Eur. J. Med. Chem. 2016, 118, 178-192. [CrossRef]

51. Vicente, S.; Pérez-Rodríguez, R.; Oliván, A.M.; Martínez-Palacián, A.; González, M.P.; Oset-Gasque, M.J. Nitric oxide andperoxynitrite induce cellular death in bovine chromaffin cells: Evidence for a mixed necrotic and apoptotic mechanism with caspases activation. J. Neurosci. Res. 2006, 84, 78-96. [CrossRef] 
52. Piotrowska, D.G.; Mediavilla, L.; Cuarental, L.; Głowacka, I.E.; Marco-Contelles, J.; Hadjipavlou-Litina, D.; López-Muñoz, F.; Oset-Gasque, M.J. Synthesis and neuroprotective properties of N-substituted C-dialkoxyphosphorylated nitrones. ACS Omega 2019, 16, 8581-8587. [CrossRef]

53. Pontiki, E.; Hadjipavlou-Litina, D.; Litinas, K.; Geromichalos, G. Novel cinnamic acid derivatives as antioxidant and anticancer agents: Design, synthesis and modeling studies. Molecules 2014, 19, 9655-9674. [CrossRef] [PubMed]

54. Chioua, M.; González-Camuñas, A.; Catarozzo, M.T.; Alcaro, S.; Ortuso, F.; Yáñez, M.; Marco-Contelles, J. Synthesis, monoamine oxidase inhibition and computational analysis of diversely substituted N-propargylated-1,3,5-triazines. ChemistrySelect 2019, 4, 8334-8337. [CrossRef]

Publisher's Note: MDPI stays neutral with regard to jurisdictional claims in published maps and institutional affiliations.

(C) 2020 by the authors. Licensee MDPI, Basel, Switzerland. This article is an open access article distributed under the terms and conditions of the Creative Commons Attribution (CC BY) license (http://creativecommons.org/licenses/by/4.0/). 